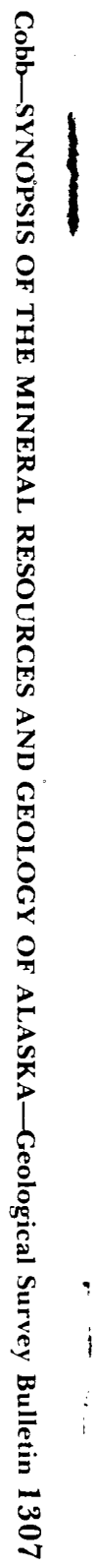

\title{
Synopsis of the
}

Mineral Resources and Geology of Alaska

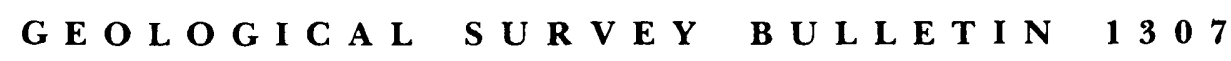

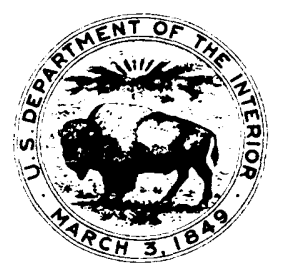

$$
\begin{aligned}
& \text { QE } 75 \\
& \text { BG } \\
& \text { No. } 1307 \\
& \mathbf{C . 6}
\end{aligned}
$$



- 


\section{Synopsis of the}

\section{Mineral Resources and}

Geology of Alaska

By EDWARD H. COBB

GE O L O G I C A L S U R V E Y B U L L E T I N 11307

Published under a cooperative agreement with the Department of Natural Resources, State of Alaska

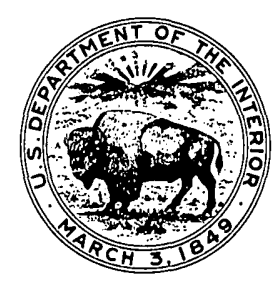




\section{UNITED STATES DEPARTMENT OF THE INTERIOR}

ROGERS C. B. MORTON, Secretary

GEOLOGICAL SURVEY

V. E. McKelvey, Director

Library of Congress Catalog-card No. 74-600019

For sale by the Superintendent of Documents, U. S. Government Printing Office Washington, D. C. 20402 - Price 70 cents (paper cover) Stock No. 2401-02478 


\section{CONTENTS}

Introduction _.

Alaska Peninsula region

Aleutian Islands region

Bering Sea region _._._.

Bristol Bay region _._-_._-_._.

Cook Inlet-Susitna River region _.

Copper River region _-_._- 13

Kenai Peninsula region _._.

Kodiak region _._.

Kuskokwim River region _._._.

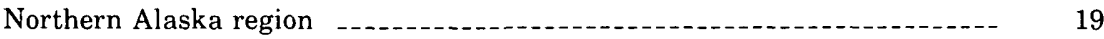

Northwestern Alaska region _._.

Seward Peninsula region _._.

Southeastern Alaska region

Yukon River region

Anvik district _..._. 26

Black district _...

Bonnifield district _._._._-_._- 27

Chandalar district _._.

Chisana district _._. 29

Circle district _.

Delta River district

Eagle district _..._- 32

Fairbanks district _._. 33

Fortymile district _.

Goodpaster district

Hot Springs district

Hughes district

Iditarod district

Innoko district

Kaiyuh district _. 41

Kantishna district _._. 42

Koyukuk district

Marshall district

Melozitna district _._. 46

Rampart district _.

Ruby district _._. 48

Sheenjek district _._.

Tok district _... 50

Tolovana district _._._._. 51

Yukon Flats district _.

References cited 


\section{ILLUSTRATIONS}

Figure 1. Mining districts and regions in Alaska

2. Physiographic provinces of Alaska..

3. Geologic map of Alaska

4. Graph showing value of minerals produced in Alaska, 1900-1972 


\title{
SYNOPSIS OF THE MINERAL RESOURCES AND GEOLOGY OF ALASKA
}

\author{
By Edward H. Совв \\ INTRODUCTION
}

This outline is an outgrowth of preparatory work for reports on the lode (Berg and Cobb, 1967) and placer (Cobb, 1972) deposits of Alaska. Essentially it summarizes data presented in those reports and in a similar report on the coal resources of Alaska prepared by Barnes (1967). Data on petroleum and natural gas were gathered from many sources, including a summary of potential petroleum resources by Gryc (1971) and annual reports of the State of Alaska Division of Geological Survey and its predecessor agencies. As the above reports contain extensive bibliographies, no reference citations are given in the body of this summary. Data are arranged by mining regions and, within the Yukon River region, by mining districts because the U.S. Geological Survey and U.S. Bureau of Mines historically have listed production data by regions or districts.

The mining regions and districts, the physiographic divisions and provinces, and the generalized geology of Alaska are shown in figures 1,2 , and 3 respectively. Figure 4 summarizes the dollar value of the mineral production of Alaska from 1900 through 1972.

\section{ALASKA PENINSULA REGION}

The Alaska Peninsula region comprises the part of the Alaska Peninsula southwest of Becharof Lake, Unimak and Chirikof Islands, and other smaller islands southeast of the mainland.

The dominant physiographic feature is the Aleutian Range, made up of northeast-trending ridges $1,000-4,000$ feet in altitude surmounted locally by volcanoes, some of which are several thousand feet higher. Northwestward the range merges with a low sand- and gravel-mantled plain that has 50-250 feet of local relief.

Geologically the Alaska Peninsula region consists of two main belts that extend for most of its length. The northwestern belt, as much as 35 miles wide in the northeastern part of the region, is predominantly unconsolidated Quaternary silt, sand, and gravel. The southeastern belt consists mainly of Mesozoic and Cenozoic sedimentary and vol- 


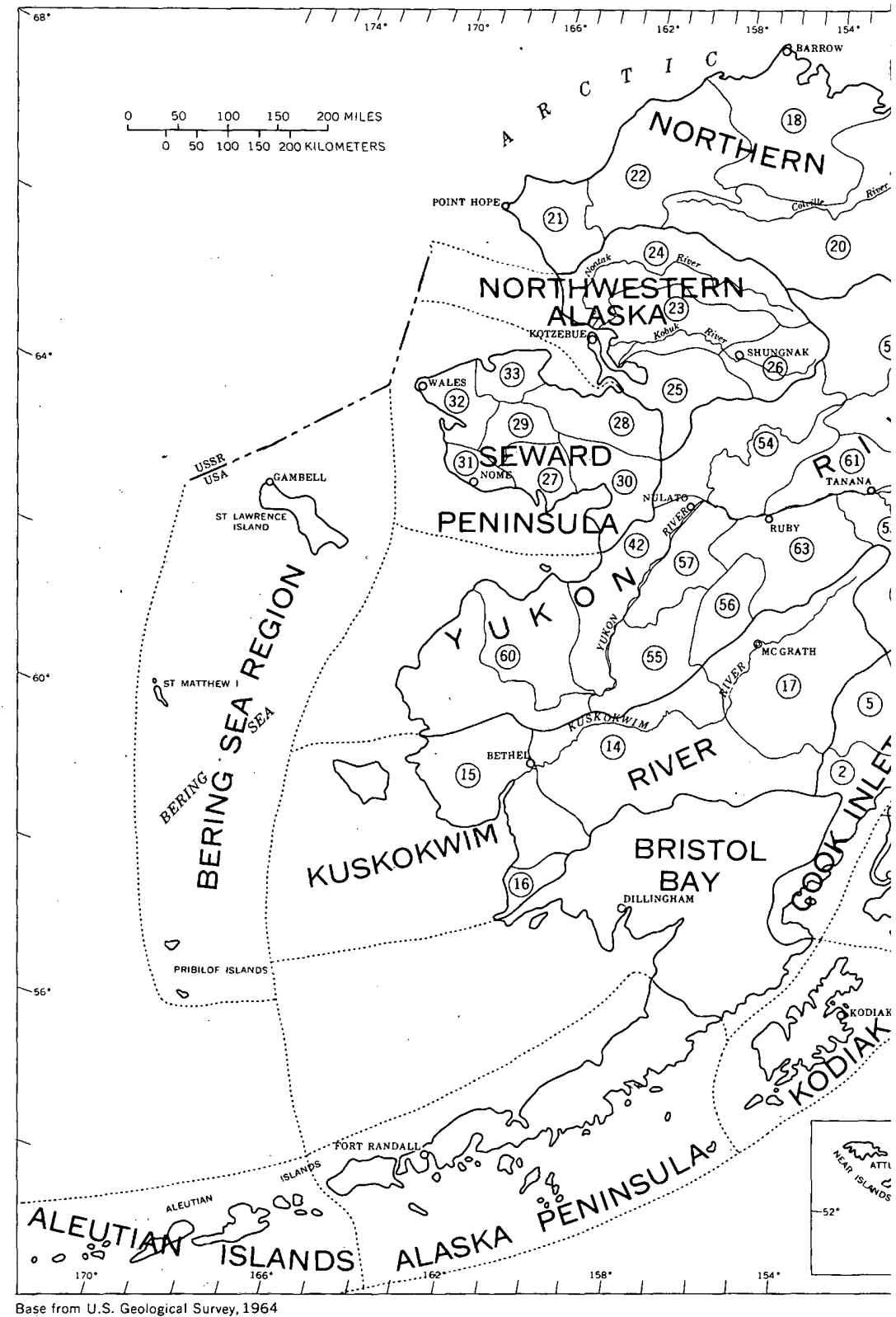

Figure 1.-Mining regions and districts in 


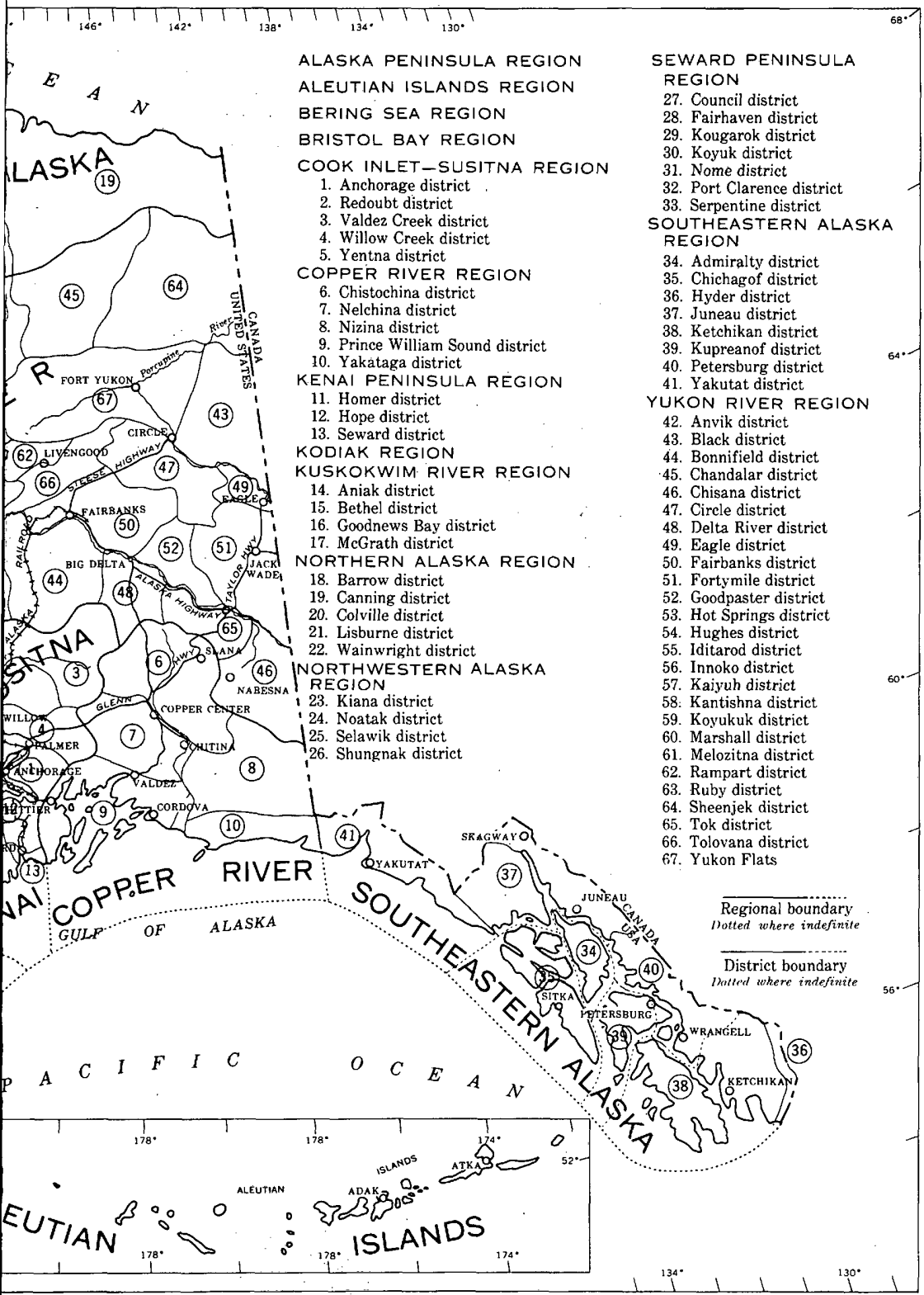

Alaska. Based on Ransome and Kerns (1954). 


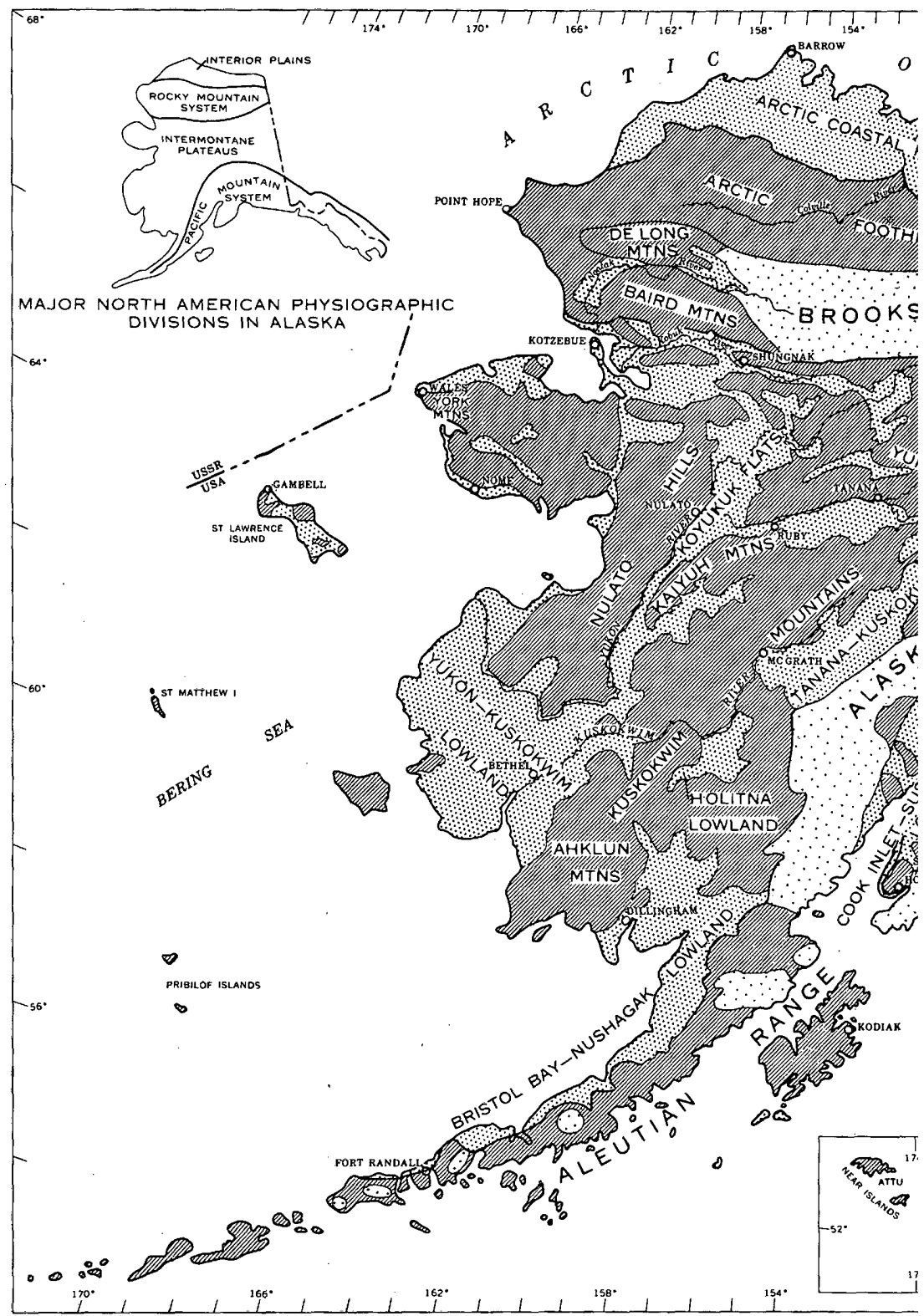

Base from U.S. Geological Survey, 1964

Figure 2.- Physiographic provinces 


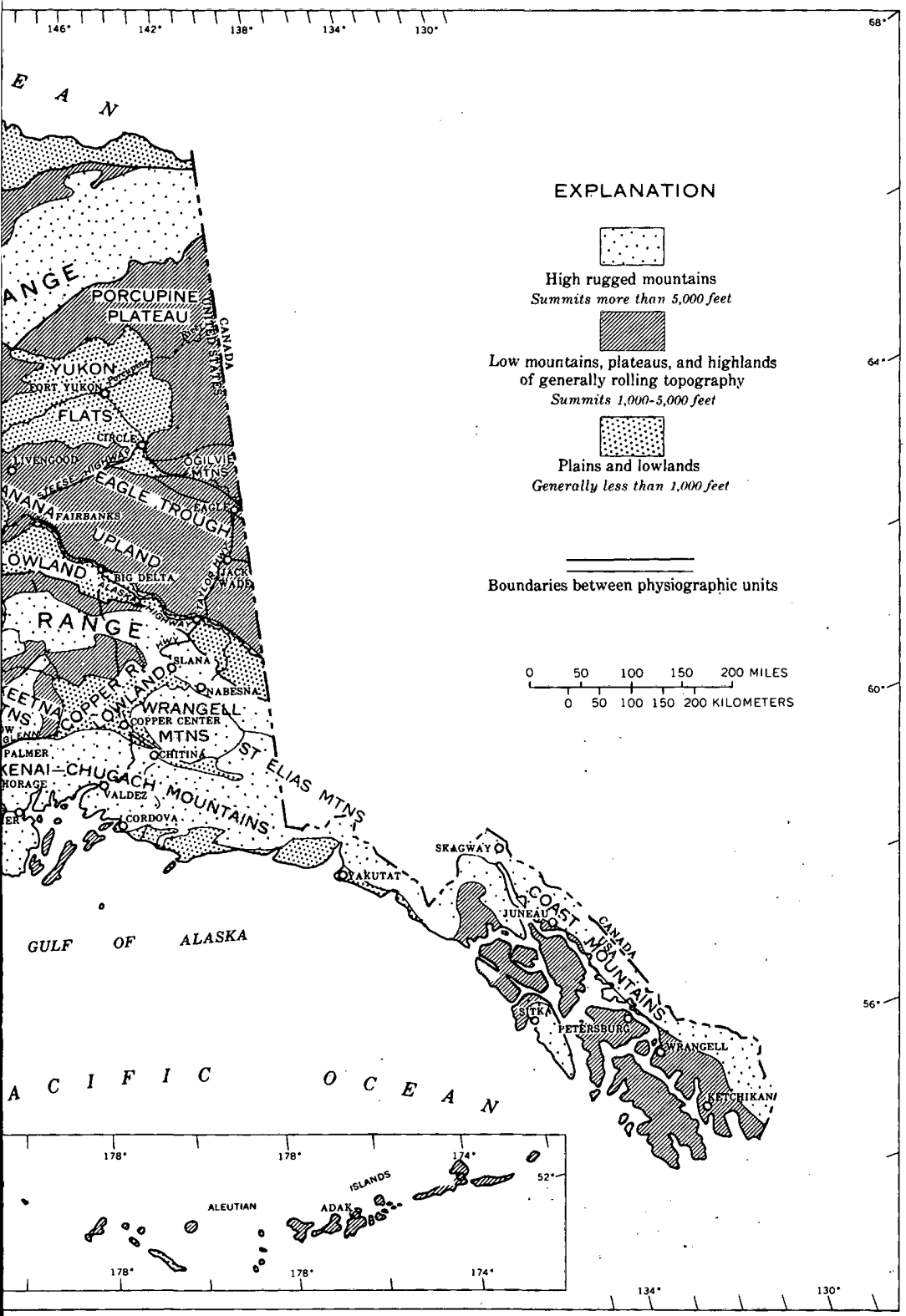

of Alaska. From Wahrhaftig (1965). 


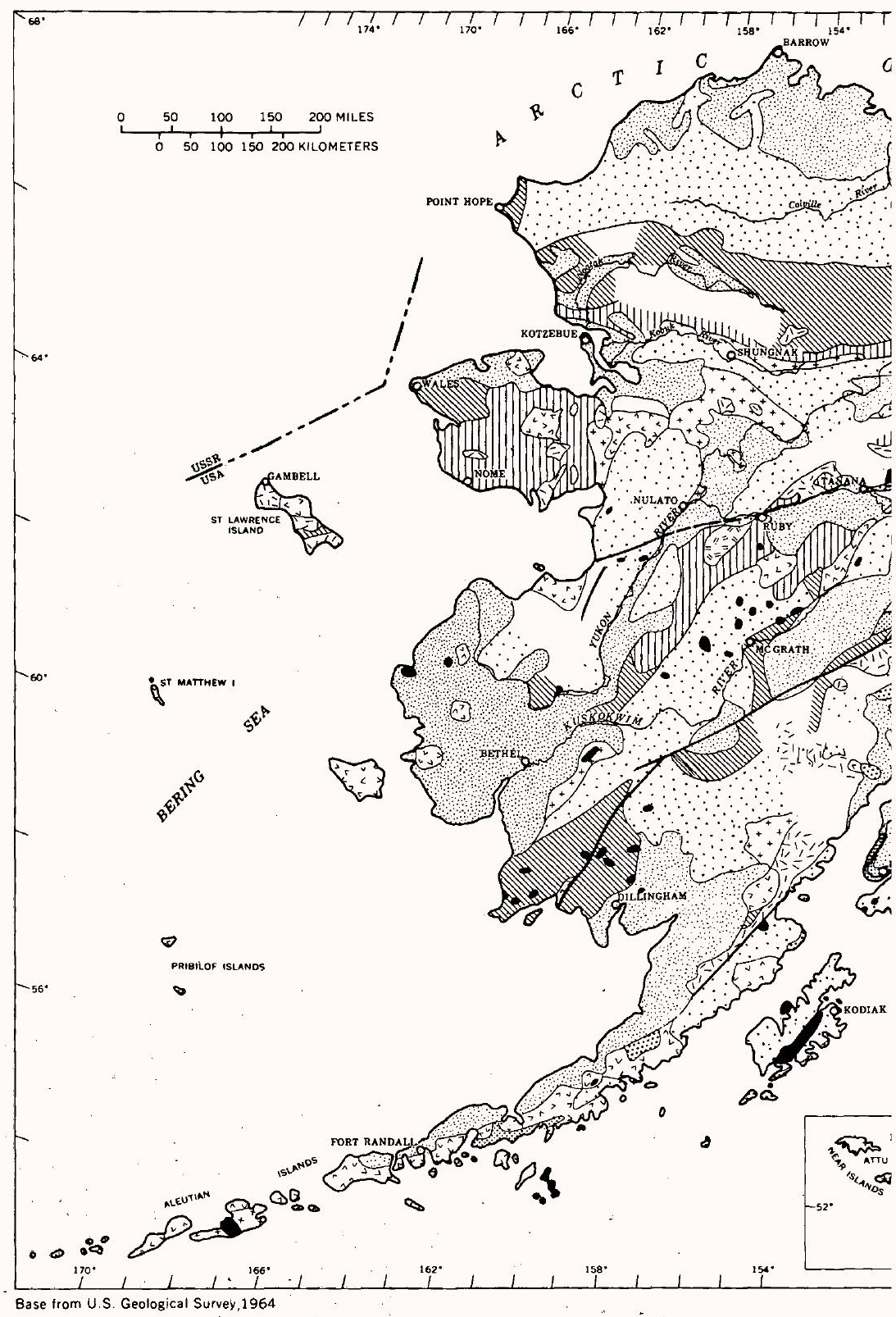

Figure 3.-Geologic map of Alaska. Based 


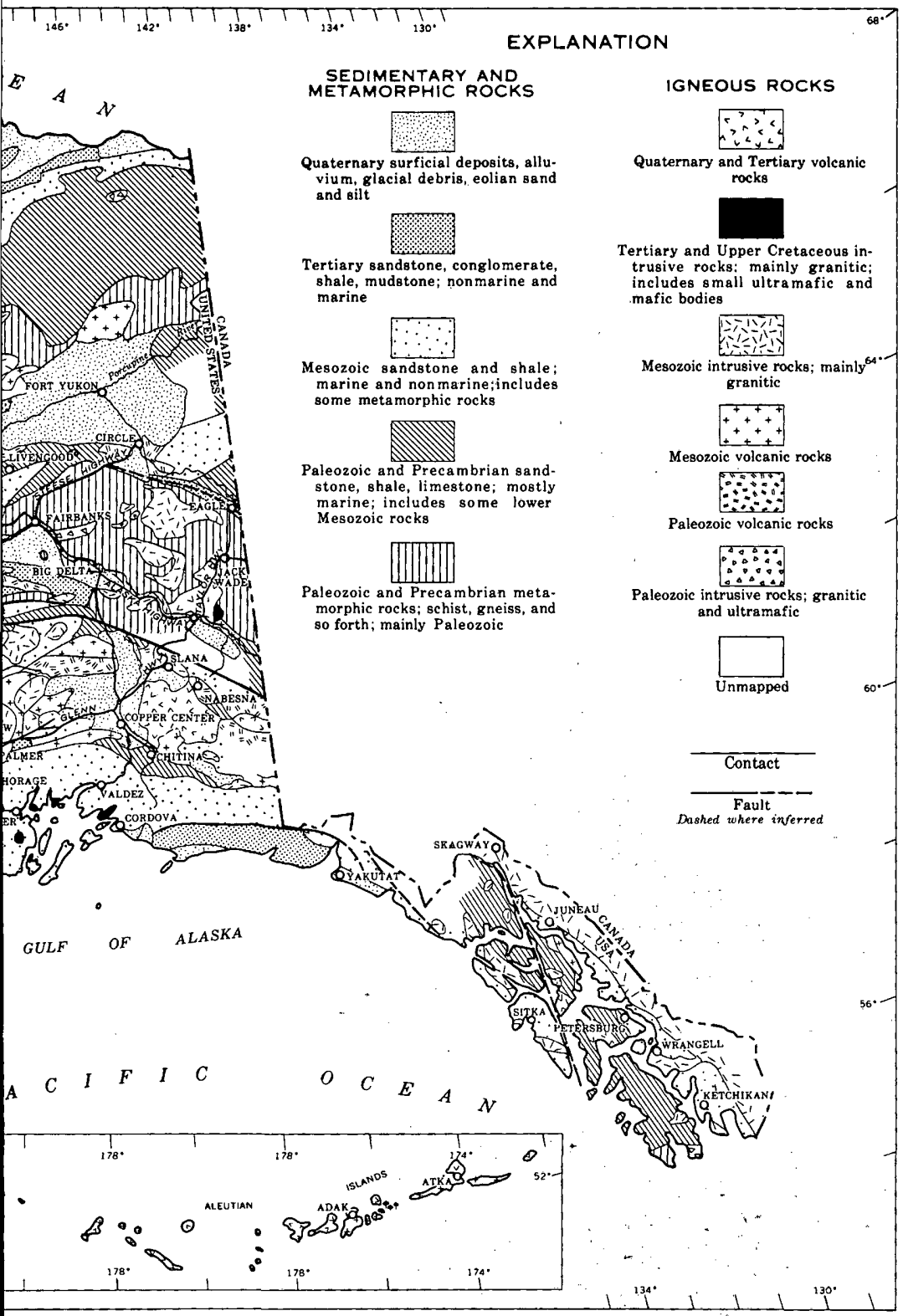

on U.S. Geological Survey (1964, fig. 8). 


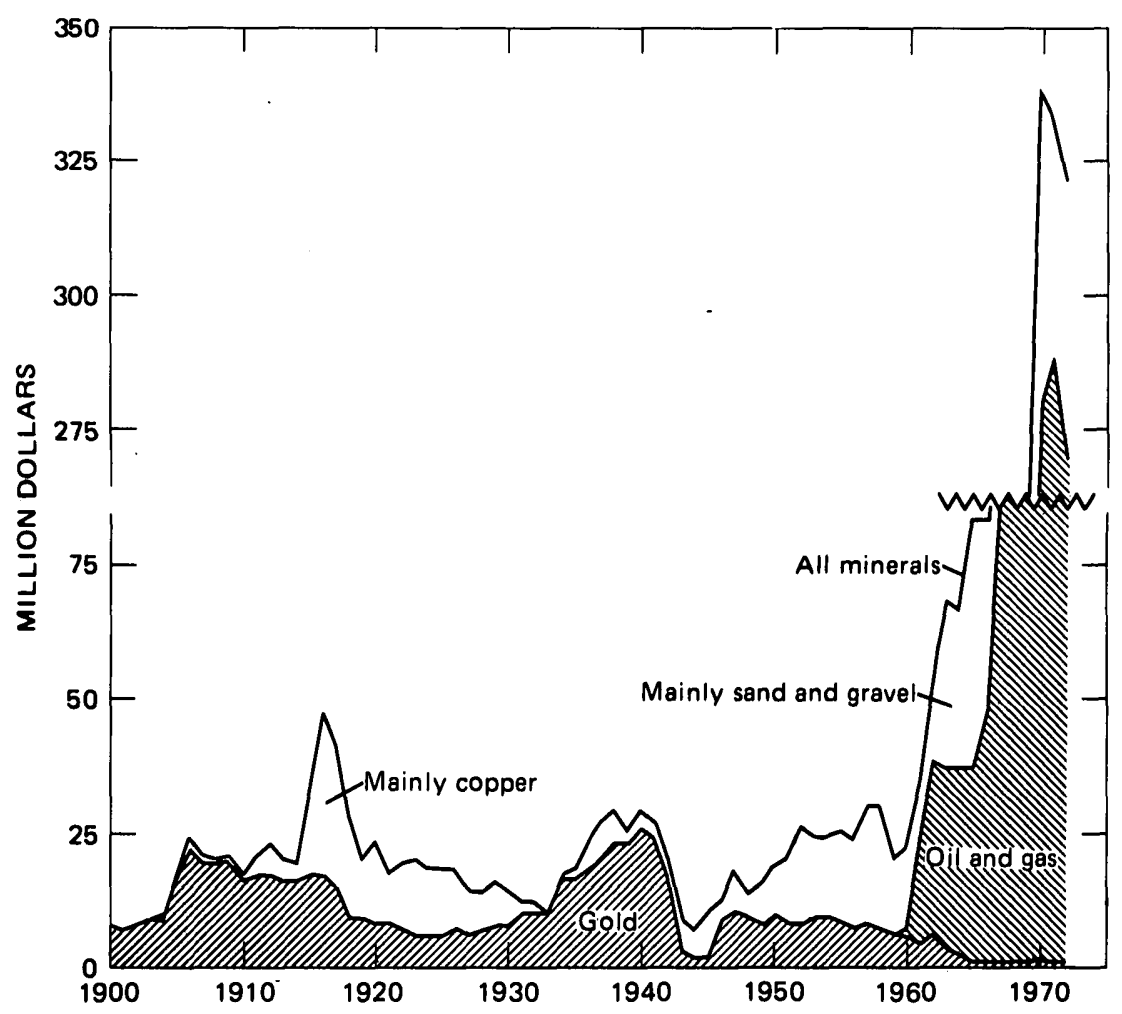

Figure 4.-Value of minerals produced in Alaska, 1900-1972.

canic rocks intruded and metamorphosed by Tertiary granitic plutons. A single exposure of unequivocally dated Permian sedimentary rocks, near Puale Bay at the northeast corner of the region, has been reported; some of the volcanic rocks probably are late Paleozoic in age also. The entire Alaska Peninsula was glaciated during the Pleistocene Epoch but now is ice free except for some of the highest peaks. The region is generally free of permafrost. Several of the volcanoes that surmount the Aleutian Range have been active within the last few years.

Lodes in the Alaska Peninsula region contain gold, silver, copper, lead, and zinc. The only ones that were worked commercially are on Unga Island, where about $\$ 2$ million, chiefly in gold and silver from the Apollo mine, was produced between 1891 and 1904. Placer gold, probably not much more than 600 ounces in all, was mined from beaches on Popof and, possibly, Unga Islands in the early 1900's. Titaniferous magnetite and ilmenite are common constituents of beach sands along the shores of Bristol Bay, but material that contains as much as 100 pounds of iron per cubic yard has been found only in a 
few places. Every few years interest is revived in almost inaccessible sulfur deposits near the head of Stepovak Bay, though no actual work has been done there. Significant coal resources are known at Chignik and Herendeen Bays and on Unga Island, but there has been no large production. Several unsuccessful test wells have been drilled for petroleum in Mesozoic and Tertiary rocks.

\section{ALEUTIAN ISLANDS REGION}

The Aleutian Islands region includes the islands west of Unimak Island. It consists of an archipelago surmounting a submarine ridge 1,400 miles long, 20-60 miles wide, and rising 12,000 feet from the sea floor. About 40 volcanoes, 21 of which have been active in historic time, form an arcuate line; the highest members rise as much as 6,975 feet above sea level.

The region is underlain by Cenozoic basalt and andesite lava flows, tuffs, and clastic rocks that were cut by mafic to felsic dikes, sills, and stocks. This region is geologically the youngest in Alaska, as all others are at least partly underlain by rocks as old as Mesozoic.

Reported and definitely located lodes in the Aleutian Islands region are restricted to gold deposits (some of which may have been productive) and metallic sulfide occurrences on Unalaska and neighboring Amaknak and Sedanka Islands. Capps reported that natives were said to have mined copper on Salt Island, a small island off the north shore of Atka; he speculated that the copper might have been from an amygdaloidal lava flow. The only placer occurrence reported from the Aleutian Islands is a few small grains of gold from a tributary of the Makushin River on Unalaska Island. There has been sporadic interest in developing sulfur deposits that have long been known on Unalaska and Akun Islands, but work never got far beyond the planning stage.

\section{BERING SEA REGION}

The Bering Sea region includes St. Lawrence, St. Matthew, and the Pribilof Islands and nearby smaller islands and offshore rocks.

The islands of the Bering Sea are mainly rolling uplands and emerged marine platforms, generally within a few hundred feet of sea level; above which isolated mountain masses rise to altitudes between 800 or 900 and about 2,000 feet. All the islands rise from the shallow Bering Shelf, much of which was emergent at times during the Cenozoic Era.

The Pribilof Islands and St. Matthew are composed mainly of Cenozoic volcanic rocks and surficial deposits, though periodotite older than the volcanic rocks has been found in a small area on St. George Island in the Pribilofs. Recent work on St. Lawrence Island, the largest in the Bering Sea, indicates that the eastern part of the island is made 
up of a thick section of Paleozoic and Mesozoic sedimentary rocks, including limestone, that are generally similar to coeval rocks exposed in the Brooks Range of northern Alaska and in the Chukotsk Peninsula of Siberia. The western part of the island is made up of similar probably correlative rocks, small areas of coal-bearing Tertiary continental deposits, and Cretaceous and Tertiary volcanic rocks. Tertiary(?) and Quaternary basaltic rocks, some very fresh and young, cover the older rocks in central St. Lawrence Island. Permian gabbro and diabase, hypabyssal phases related to some of the volcanic rocks, and Cretaceous quartz monzonite and olivine monzonite plutons invaded the older rocks in both the eastern and western parts of the islands.

The known lode deposits on St. Lawrence Island include disseminated molybdenite in one of the plutons, a small low-grade porphyry copper deposit with minor molybdenite in a small satellitic stock, and several small sulfide deposits containing lead, zinc, and silver. These lode deposits have been little explored. An old report of cassiterite having been found near the southwest end of the island did not specify if it was a bedrock or placer occurrence. Recent stream-sediment sampling and reconnaissance geologic mapping in the area, however, failed to find any indication of tin mineralization. With the possible exception of this rumor of cassiterite, no placer deposits have been reported from the land area of the Bering Sea region. There has been, however, very little prospecting in the region, owing in part to its remoteness and in part to governmental restrictions.

Recent investigations in the Bering Sea suggest that local concentrations of gold in bottom sediments, particularly between St. Lawrence Island and the Seward Peninsula, and possibly petroliferous Cenozoic basins in the northern and southern parts of the region might be attractive exploration targets.

\section{BRISTOL BAY REGION}

The Bristol Bay region inclddes the area drained by streams flowing into Bristol Bay from Cape Newenham on the west to Egegik Bay on the east, and into Shelikof Strait from Cape Douglas on the north to Cape Kekurnoi on the south.

The southeast border of the region is part of the Aleutian Range of the Pacific Mountain System; northwest of them are lower mountains, plateaus, and basins of the Intermontane Plateaus. The highest peaks are mainly Quaternary volcanoes, some active in historic time, with summit elevations of 5,000 to 7,500 feet. The Bristol Bay-Nushagak Lowland is a lake-dotted area less than 1,000 feet above sea level, above which isolated hills rise a few hundred to slightly more than 2,000 feet. The Ahklun Mountains in the western part of the region are 
a low but rugged range with many large deep lakes of extraordinary scenic grandeur.

The mountains in the eastern part of the Bristol Bay region consist of rocks that range in age from possibly Permian metamorphosed volcanic rocks (seen only in a few isolated exposures) to Tertiary and Quaternary lava flows and fragmental rocks. The bulk of the bedded rocks, however, are Mesozoic sandstone, shale, and conglomerate. Northwest of a major lineament (Bruin Bay fault) the older rocks were invaded and locally metamorphosed by diorite and quartz diorite that make up the Aleutian Range batholith of Jurassic age. There are also smaller younger felsic and mafic plutons and volcanic necks.

In the western part of the region, bedrock consists mainly of clastic and volcanic rocks of Carboniferous to Cretaceous age and Tertiary felsic and mafic dikes, sills, and small plutons. Between the eastern and western mountains, the region is a lowland underlain by thick glacial and alluvial deposits with bedrock exposed only around its margins and in a few hills that protrude through the surficial materials. Except for its north-central part, the region was glaciated. It is now mainly in zones characterized by isolated masses of permafrost.

Lode deposits containing mercury, gold, silver, copper, lead, zinc, antimony, and iron are known in the Bristol Bay region, but little ore has been produced from them. The greatest recent interest has been in low-grade iron deposits in the eastern part of the region, in a copperiron deposit near Lake Clark, and in a mercury deposit (from which there has been small production) at Marsh Mountain north of Dillingham.

The part of the region on the Alaska Peninsula has been the scene of considerable exploration for petroleum, but no commercial oil or gas field has been discovered. Interest has also been shown in pumice and pumicite in the southeastern part of the region for use as a component of light-weight concrete aggregate. In 1947 a few tons of this material was mined at Geographic Harbor about 15 miles northeast of Katmai Bay.

\section{COOK INLET-SUSITNA RIVER REGION}

The Cook Inlet-Susitna River region is the area drained by streams flowing into Cook Inlet between Cape Douglas on the south and the east end of Turnagain Arm. It is divided into the Anchorage, Redoubt, Valdez Creek, Willow Creek, and Yentna districts.

The region is entirely within the Pacific Mountain system. Its west and north borders are along the east and south slopes of the Alaska Range and its southeastern boundary is the crest of the lower, but no less rugged, Chugach Mountains. The region includes another highland area, the Talkeetna Mountains, a nearly circular mountain mass with most peaks between 6,000 and 8,300 feet in elevation. The east- 
ern boundary of the region is an ill-defined divide in the western part of the poorly drained lake-speckled Copper River Lowland. A somewhat poorly drained area, the Cook Inlet-Susitna Lowland, is an extension of Cook Inlet; it separates the southern Alaska Range from the Talkeetna Mountains. Low mountains and ranges of hills rise from a few hundred to a few thousand feet above the lowland, particularly near the foothills of the Alaska Range.

The oldest geologic units in the region are Paleozoic clastic and carbonate rocks, exposed mainly in the Alaska Range, that are now being studied in detail. Mesozoic and early Tertiary volcanic and clastic rocks, locally with considerable interbedded limestone, make up the bulk of the bedded rocks in the Chugach Mountains, the northern part of the Alaska Peninsula, the hills rising from the Cook Inlet-Susitna Lowland, and areas bordering the Copper River Lowland. Large batholiths of Jurassic, Cretaceous, and Tertiary age that consist of granodiorite, quartz monzonite, and related rock types invaded the older sedimentary and volcanic rocks in the Talkeetna Mountains and Alaska Range. Smaller plutons are in the Chugach Mountains and other parts of the region. The middle part of a discontinuous belt of small ultramafic bodies of probable Paleozoic age that extends from Kodiak Island to the St. Elias Mountains is in the Anchorage district.

Tertiary continental deposits underlie Cook Inlet and large areas in the Susitna Lowland and Matanuska Valley and small areas in the northeastern part of the Valdez Creek district. Tertiary and Quaternary volcanic rocks have been found in the Matanuska Valley and west of Anchorage, and in the southern Alaska Range, where Augustine Island and some of the highest peaks are active volcanoes. Much of the Cook Inlet-Susitna Lowland and the western part of the Copper River Lowland are underlain by thick glacial and alluvial deposits. Except along Cook Inlet and some of the large rivers, most of the region is underlain by permafrost. Ice completely covered this part of Alaska during the Pleistocene, spreading from the Alaska Range far out to sea. Ice still covers the highest parts of the mountains, and valley glaciers, one more than 35 miles long, extend far from their source areas.

Gold and silver have been recovered from lodes in many parts of the Cook Inlet-Susitna region and a little copper from deposits in the Redoubt and Valdez Creek districts. These and other lodes have also been investigated as possible sources of antimony, iron, chromite, molybdenum, copper, lead, and zinc. In the southern Alaska Range metallic sulfide minerals are common in and near granitic plutons. Float samples collected in the vicinity of one pluton in the southwestern part of the Yentna district contained as much as 60 parts per 
million (about 1.7 ounces per ton) of gold associated with chalcopyrite, arsenopyrite, and other sulfides. The only large-scale production, however, was from the Willow Creek area north of Palmer where between 1909 and World War II gold-bearing quartz veins in the southern border zone of the Talkeetna batholith were the source of about 404,425 ounces of gold, 5 percent of Alaska's total lode gold output. Minor amounts of gold, silver, and base metals have been produced from the upper Chulitna area near the Alaska Railroad. Total metallic resources are large and, in the future, might well become important to the Alaskan economy.

Placer gold was discovered in the Cook Inlet-Susitna River region in the late 19th century, and mining has been carried on continuously since the early 1900 's. Output was probably about 250,000 ounces, or less than 70 percent of the lode-gold production. The bulk of the placer gold has come from steams that drain the Dutch Hills and Fairview Mountain in the Yentna district, from Valdez Creek in the Valdez Creek district, and from Crow Creek in the Anchorage district.

Other mineral resources that have been exploited include pumice from Augustine Island, minor amounts of ceramic clay and agricultural lime from near Anchorage, a little gypsum and clay from Sheep Mountain in the upper Matanuska Valley, soapstone (for carving) from near Palmer, and large amounts of construction materials along railroad and highway routes and near Anchorage, the largest metropolitan area in the state. Limestone deposits in the northwestern part of the Valdez Creek district and in the Matanuska Valley east of Palmer have been investigated as possible sources of raw material for portland cement.

Oil and gas produced from fields in Cook Inlet and southeast of it in the Homer and Hope districts of the Kenai Peninsula region have far outshadowed all other mineral commodities in value; since 1959 the value of this hydrocarbon production has been greater than $\$ 1 / 4$ billion and constitutes almost the entire production of the State.

There are large resources (more than $2^{1 / 2}$ billion short tons) of bituminous and subbituminous coal in the Matanuska Valley of the Willow Creek district, in the Tyonek-Beluga River area of the Redoubt district, in the central part of the Yentna district, and near Broad Pass in the Valdez Creek district. Extensive mining has been carried on only in the Matanuska Valley.

\section{COPPER RIVER REGION}

The Copper River region includes the area drained by the Copper River and its tributaries, the area east of the divide between Prince William Sound and Cook Inlet, the area drained by streams flowing into the Gulf of Alaska between the Copper River and $141^{\circ}$ west longitude, and 
offshore islands, including Middleton Island. It is divided into five districts: Chistochina, Nelchina, Nizina, Prince William Sound, and Yakataga.

The region is in the Pacific Mountain System and includes parts of the Alaska Range, Wrangell, St. Elias, and Kenai-Chugach Mountains, and Copper River Lowland physiographic provinces. The mountains, which rise to summits more than 16,000 feet in elevation in the Wrangells and to more than 18,000 feet at Mount St. Elias, support and nourish the largest ice fields and piedmont ice lobes and some of the longest valley glaciers in North America; all are remnants of Pleistocene ice that covered most of the region. The Copper River Lowland and the Chitina Valley are largely mantled by thick accumulations of Pleistocene and Holocene glacial, lacustrine, and fluvial deposits that are frozen to depths of several hundred feet. The islands and most of the shores of Prince William Sound, the Copper River delta, and the lowlands and low mountains bordering the Gulf of Alaska in the Yakataga district are generally free of permafrost.

Bedrock in the Copper River region ranges in age from late Paleozoic to Quaternary. The bulk of the rocks are of Mesozoic age, and they include great thicknesses of graywacke, slate, and greenstone and lesser amounts of carbonate rocks. In late Mesozoic and early Tertiary time, plutons, some of batholithic dimensions, invaded older rocks in many parts of the region. Most are composed of granodiorite, quartz diorite, and related rock types. The largest are in the Alaska Range and the Chugach and St. Elias Mountains.

In the Yakataga district complexly deformed Tertiary and lower Pleistocene marine and continental rocks underlie the area between the crest of the Chugach Mountains and the Gulf of Alaska. Some may be continuous with similar coeval rocks in Cook Inlet and on Kodiak Island. They extend at least as far offshore as Middleton Island, the highest part of a broad topographic feature that rises abruptly from the continental shelf. The most prominent formation in the Wrangell Mountains is the Wrangell Lava, a thick pile of Tertiary and Quaternary andesitic flows and associated rocks. Mount Wrangell $(14,005 \mathrm{ft})$ still emits steam and ash.

Lodes in many parts of the Copper River region contain copper, gold, silver, molybdenum, antimony, nickel, chromite, iron, lead, and zinc, but only copper, gold, and byproduct silver were mined commercially. The famous Kennecott mines near McCarthy in the Nizina district and mines in the southwestern and northeastern parts of Prince William Sound accounted for most of the copper (690,000 short tons) produced in Alaska. Two or three million dollars worth of gold and smaller amounts of silver came from mineralized quartz and calcite veins in graywacke, slate, and granitic rocks and as byproducts of copper min- 
ing in the Prince William Sound district. Similar veins in the southeastern part of the Nelchina district were mined in a small way, but the entire region was not a significant contributor to the total lode gold production of Alaska.

Placer deposits have been worked in all the districts of the Copper River region, but the total production was probably less than 350,000 ounces of gold and a few ounces of platinum. Placers near the head of the Chistochina River (derived from gold-bearing Tertiary continental rocks and glacial deposits) and near Slana in the Chistochina district probably accounted for 150,000-160,000 ounces of gold and all the platinum, deposits in the north-central part of the Nizina district for about the same amount of gold, and beach and stream placers in the Yakataga and Nelchina districts for almost all the remainder. Production from the Prince William Sound district probably did not exceed 500 ounces. About 40 tons of native copper was recovered from Dan Creek in the Nizina district, and copper is a constituent of concentrates from neighboring streams.

The first successful oil well in Alaska was drilled in Tertiary rocks near Katalla in the western part of the Yakataga district in 1902. Although more wells, all shallow, were drilled during the ensuing 30 years, total production was only about 150,000 barrels. A few miles to the north, Tertiary coal-bearing rocks underlie an area of about 50 square miles in the Bering River coal field. Prospecting has failed to develop a commerical mine, probably because of the great structural complexity of the area. Other than road metal and some construction materials for local use, no nonmetallic mineral resources have been developed in the Copper River region.

\section{KENAI PENINSULA REGION}

The Kenai Peninsula region is the Kenai Peninsula south of Turnagain Arm and west of the divide between Cook Inlet and Prince William Sound. It is divided into the Homer, Hope, and Seward districts.

The region, which is entirely within the Pacific Mountain System, includes parts of two major physiographic provinces. West of a line extending from the head of Kachemak Bay to Turnagain Arm is an area of subdued relief that is part of the Cook Inlet-Susitna Lowland. Most of it is considerably less than 1,000 feet above sea level, but rolling hills and a few steep-sided ridges rise to elevations of nearly 3,000 feet. The rest of the Kenai Peninsula, part of the Kenai-Chugach Mountains, is characterized by high relief with many of the summits between 4,000 and more than 6,000 feet in altitude. Deep fiords, many with glaciers at their heads, embay its southeastern coastline. Remnants of Pleistocene ice that covered the entire peninsula and extended 
far to sea are preserved as alpine glaciers and ice fields. The entire region is free of permafrost.

The Kenai Mountains, the highest parts of which are virtually unexplored, are made up of limestone, chert, and tuff of Triassic age that rest on metamorphosed older volcanic and clastic rocks of possible Paleozoic age and are in fault contact with Jurassic volcanic rocks and a thick sequence of intensely deformed but only slightly metamorphosed slate and graywacke, mainly of Late Cretaceous age. These rocks were intruded by Tertiary(?) granitic dikes, sills, and stocks. The Kenai Lowland and adjacent parts of Cook Inlet are underlain by many thousand feet of poorly consolidated, mainly continental, rocks of Tertiary age that rest on rocks similar to those exposed in the Kenai Mountains. These Tertiary rocks are buried by Quaternary deposits except along sea cliffs and in isolated inland exposures.

Only gold, alloyed with silver, and chromite have been mined from lodes in the Kenai Peninsula region, though copper, lead, zinc, molybdenum, antimony, and nickel minerals also have been found in them. Nearly 30,000 long tons of chromite with an average $\mathrm{Cr}_{2} \mathrm{O}_{3}$ content of about 45 percent has been mined from two dunite and pyroxenite stocks in the southern part of the Homer district. In the eastern part of the Hope district and at Nuka Bay in the Homer district, quartz veins in graywacke and slate near small quartz diorite stocks and granite dikes and in the intrusive bodies themselves are hosts for gold and various sulfide minerals. The lode-gold production of the region probably was about 19,000 ounces.

Placer gold was discovered in 1848 on the Kenai River by P. P. Doroshin, a mining engineer in the employ of the Russian-American Company, but the gold was not in sufficient quantities for profitable mining at that time. Later placer mining was concentrated in the part of the Hope district where lode deposits were most extensively explored and mined, though a few streams and beaches in other parts of the Kenai Peninsula region where potentially valuable lodes have not been found were worked on a small scale. Total placer production from the Kenai Peninsula region since about 1895 was probably between 100,000 and 105,000 ounces of gold.

The first major oil discovery in Alaska was in 1957 in the Swanson River field near Cook Inlet in the western part of the Hope district. This general area, Cook Inlet itself, and the adjoining parts of the Cook Inlet-Susitna River region have been the source of almost all of Alaska's petroleum production (see section on "Cook Inlet-Susitna River Region").

The first coal mine in Alaska was opened by Russians in 1855 at Port Graham in the southwestern part of the Homer district, and a few years later small-scale mining began near Homer. Total production 
from the Kenai Peninsula, however, probably did not exceed a few thousand tons of subbituminous coal and lignite, almost all for local use. Total resources are estimated to be about 318 million short tons. Other than sand and gravel, no nonmetallic mineral resources in the Kenai Peninsula have been exploited, though deposits of diatomaceous earth, limestone, clay, and material possibly useful for manufacturing light-weight aggregate have been investigated.

\section{KODIAK REGION}

The Kodiak region includes Kodiak, Afognak, and the Trinity Islands and nearby small islands. The region is characterized by mountains with summits $2,000-4,000$ feet in altitude and by gently rolling uplands. Long narrow inlets extend well into the interiors of Kodiak and Afognak Islands.

Most of the region is underlain by Cretaceous graywacke, slate, and conglomerate and older Mesozoic and probable Paleozoic marine and volcanic rocks containing a few small mafic and ultramafic bodies. These units and overlying early Tertiary volcanic and marine sedimentary rocks were invaded and locally metamorphosed by quartz diorite plutons, some of batholithic dimensions, in early Tertiary time. Younger Tertiary marine and continental rocks form the Trinity Islands and a fringe along the southeastern coast of Kodiak Island. Quaternary glacial and fluvial deposits mantle bedrock in low areas on western Kodiak Island, at the heads of bays, and along some of the larger streams. Long faults, some thrust and others steep with predominantly vertical movement, extend the length of the major islands. Outcrop and fault patterns give the region a pronounced northeasttrending grain that, if extended, would join generally similar features at the southwest end of the Kenai Peninsula. The Kodiak region was covered by Pleistocene ice that extended from the crest of the Aleutian Range across the islands and several tens of miles into the Pacific Ocean. Glaciation removed most unconsolidated material and any placer deposits that may have been formed in preglacial valleys. Ice remains in a few cirque glaciers on the highest peaks on Kodiak Island.

An unknown, but probably small, amount of gold was mined from several lode deposits in the Kodiak region, mainly before World War I and in the 1930's. The known lode occurrences of tungsten and copper have proved to be too small and too low grade to be mined.

The only placers that have been found in the region are in beach deposits where gold was concentrated from glacial outwash and till. Most placer mining was on the west coast of Kodiak Island where wave action concentrated heavy minerals in a veneer of material in transit across a planation surface cut on glacial deposits. Ninety-five percent of the concentrates was magnetite. Other heavy minerals in the con- 
centrates include pyrite, chromite, gold, and a little platinum.

The total production of gold probably was not more than a few thousand ounces.

Current interest in the mineral resources of the region is mainly in the possibility of finding petroleum in Shelikof Strait and on the outer continental shelf in the Gulf of Alaska.

\section{KUSKOKWIM RIVER REGION}

The Kuskokwim River region includes Nunivak and Nelson Islands and the mainland area drained by streams flowing into Baird Inlet, Etolin Strait, and Kuskokwim Bay. It is divided into the Aniak, Bethel, Goodnews Bay, and McGrath districts.

Most of the Kuskokwim River region is in the Intermontane Plateaus physiographic division and is dominated by the Kuskokwim Mountains, a succession of rounded northeast-trending ridges $1,500-2,000$ feet in altitude surmounted locally by rugged mountains as much as 2,000 feet higher. Other upland areas include the Kilbuck Mountains and parts of Nunivak Island. The eastern boundary of the region is the crest of the southern Alaska Range, most of which is more than 6,000 feet in elevation. About a third of the region consists of parts of the Yukon-Kuskokwim and Kuskokwim-Tanana Lowlands and all of the Holitna Lowland, areas less than 1,000 feet in altitude.

The oldest rocks, exposed as a narrow belt of gneiss and schist about 75 miles long in the western part of the region, are certainly older than Devonian and may be Precambrian in age. Paleozoic sedimentary rocks range in age from Cambrian to Devonian in the Alaska Range and from Devonian to Permian in the Kuskokwim Mountains. In the western part of the region, sedimentation, interspersed with volcanic activity, was virtually continuous through Mesozoic and Tertiary time. A great thickness, possibly as much as 5 or 6 miles, of graywacke, shale, conglomerate, volcanic rocks, and limestone underlies most of the area west of the Alaska Range and its foothills. These rocks were displaced along major northeast-trending zones of strike-slip faulting, some of which can be traced far beyond the boundaries of the region.

Tertiary and Quaternary basaltic lava flows and associated tuffs cover most of Nunivak and Nelson Islands. Upper Cretaceous and Tertiary plutons, dikes, and sills intruded the older rocks in nearly all parts of the region. The intrusive rocks range in composition from ultramafic to felsic, but most are granodiorite, quartz monzonite, and similar rock types. Quaternary fluvial and glacial deposits that locally have been reworked by wave and wind action floor the lowlands and valleys. Most of the surficial deposits are perennially frozen except near large bodies of water; many of the mountainous parts of the region are in areas underlain by discontinuous or isolated masses of 
permafrost. Only the Alaska Range, the mountains in the southwestern part of the region, and isolated summits of the Kuskokwim Mountains nourished Pleistocene glaciers, remnants of which are preserved in cirques and valleys in the Alaska Range.

Lodes in the Kuskokwim River region have been the source of almost all the mercury mined in Alaska, a total of about 40,000 76 -pound flasks since 1902 . Some gold and a little byproduct antimony ore have also been mined. Other lodes, some of which were fairly extensively prospected, contain gold and various copper, lead, zinc, molybdenum, arsenic, tungsten, bismuth, antimony, mercury, manganese, and uranium minerals. Many occurrences of base and precious metals in the eastern parts of the Aniak and McGrath districts are in bedrock, and others consist of mineralized float that cannot have travelled far from lode sources in and near contact zones around granitic plutons.

Most of the mercury deposits consist of ore bodies that carry cinnabar, with or without stibnite, associated with diabase dikes (now altered to rocks composed of silica, carbonate, and clay minerals) that cut graywacke and shale. North of Medfra in the McGrath district auriferous lodes in recrystallized limestone intruded by quartz monzonite plutons were the source of 40-60 thousand ounces of gold and a little silver.

Prospectors looking for gold passed through the Kuskokwim River region as early as 1889 , but no placer deposits were found until about 1900. Placer gold production since 1908 has been about 650,000 ounces, approximately 3.2 percent of the total for the State. The major producing area was near Nyac in the Aniak district; significant amounts of gold álso came from streams in the Bethel, Goodnews Bay, and McGrath districts. Platinum or mercury accompanies gold in most of these placers. The Salmon River drainage near Platinum in the southwestern part of the Goodnews Bay district has been the source of well over half a million ounces of platinum-group metals, a major portion of the primary production of the United States. These deposits are still being actively mined. Scheelite was mined as a byproduct of gold from Fortyseven Creek in the central part of the Aniak district.

No occurrences of potentially valuable nonmetallic mineral commodities or mineral fuels have been reported from the region, though there are a few thin beds of probably bituminous coal on Nelson and Nunivak Islands.

\section{NORTHERN ALASKA REGION}

The northern Alaska region is the part of Alaska drained by streams flowing into the Arctic Ocean and Chukchi Sea from the AlaskaYukon boundary ( $141^{\circ}$ west longitude) on the east to and including the 
Wulik River on the southwest. The region is divided into the Barrow, Canning, Colville, Lisburne, and Wainwright districts.

The region lies wholly within the Interior Plains and Rocky Mountain System physiographic divisions and includes the Arctic Coastal Plain, nearly all the Arctic Foothills, and about half of the Brooks Range and DeLong Mountains. The lake-dotted coastal plain rises gradually from the Arctic Ocean to a maximum altitude of 600 feet at its south margin, where it merges with rolling plateaus and uplands. The southern part of the region is marked by rugged east-trending mountains 4,000-8,000 feet in altitude.

The bedded rocks form two east-trending belts: a southern belt of Paleozoic carbonate and clastic rocks and a northern belt of Mesozoic mainly clastic rocks. Tertiary conglomerate, sandstone, and siltstone underlie parts of the Canning and Colville districts. The Paleozoic and Mesozoic rocks were displaced northward along folds, nappes, and thrust faults, along some of which there were many miles of movement: In the Romanzof Mountains in the eastern part of the Canning district, granitic rocks invaded bedded rocks of pre-Mississippian age. In the western Brooks Range and the Arctic Foothills, Jurassic mafic intrusive bodies cut the older rocks. The Arctic Coastal Plain is covered by Quaternary silt, sand, and gravel.

In northern Alaska only the Brooks Range and DeLong Mountains supported extensive Pleistocene glaciers, small remnants of which form isolated cirque glaciers. The entire region is in a zone of continuous permafrost, which reaches thicknesses of many hundreds of feet.

Economic interest in northern Alaska has been focused mainly on fossil fuels. In 1968 one of the largest oil discoveries in North America was made at Prudhoe Bay near the mouth of the Sagavanirktok River in the Canning district. Other smaller oil and gas fields were found while exploring Naval Petroleum Reserve No. 4 during and after World War II. Total proved reserves of known fields are about 10 billion barrels of oil and about 26 trillion cubic feet of gas. Oil shale, some very rich, is widely distributed along the Brooks Range. Between Cape Lisburne and the Colville River, coal occurs in Paleozoic and Mesozoic rocks. Very conservative estimates of the total coal resources under less than 3,000 feet of overburden are 9,292,000,000 tons of bituminous coal in beds more than 14 inches thick and $100,905,000,000$ tons of subbituminous coal in beds more than $2 \frac{1 / 2}{2}$ feet thick. A little gas near Barrow and small tonnages of coal from several places near the coast have been produced for local use.

No metallic lode deposits have been reported from northern Alaska although from time to time Eskimos have brought to Barrow specimens of galena and sphalerite, the sources of which are not known. Small amounts of gold have been found in the drainages of the Firth, 
Malcolm, and Kongakut Rivers in the eastern part of the Canning district, but no valuable placer deposits have been discovered anywhere in the northern Alaska region. Phosphatic materials in amounts or concentrations of no commercial importance under present economic conditions occurs in Carboniferous and Triassic rocks.

\section{NORTHWESTERN ALASKA REGION}

The northwestern Alaska region is the area drained by streams flowing into Kotzebue Sound from the Wulik River on the north to (and including) the Kauk River on the south. It is divided into the Kiana, Noatak, Selawik, and Shungnak districts.

The region includes the Baird Mountains, part of the Brooks Range, and diverse parts of lower uplands and lowlands drained mainly by the Noatak, Kobuk, and Selawik Rivers. Most of the mountains are in rugged eastward-trending groups 3,000-5,000 feet in altitude that are separated by lake-dotted tundra-floored lowlands. A few peaks in the eastern part of the region reach altitudes of more than 8,000 feet.

In the northern part of the region, which is still incompletely mapped, the bedded rocks include limestone and marble, dolomitic limestone (some reefoid), and metamorphosed clastic and volcanic rocks, most of which are of early Paleozoic age, though some of the volcanic rocks are as young as Jurassic. These rocks have been complexly folded and displaced by thrust and normal faults. Mafic and ultramafic bodies of probable Jurassic age cut the older rocks near Misheguk Mountain and north of the Kobuk River. Cretaceous clastic rocks overlie the older units. In the southern part of the region, the bedded rocks are mainly Cretaceous clastic and volcanic rocks that were intruded by granitic plutons, some of which are alkalic. The Mesozoic rocks are overlain by Tertiary and Quaternary basalt flows. Most of the lowland areas are covered by thick deposits of Quaternary fluvial, glacial, eolian, and marine sand, silt, and gravel.

Pleistocene ice covered northwestern Alaska except for parts of the Baird Mountains and the southern part of the Selawik district. Now, however, only a few cirque glaciers remain. The region is underlain by continuous permafrost except for an area in the Selawik district and along some of the larger streams.

Lodes potentially valuable for copper have been found in the Kiana, Noatak, and Shungnak district, but only one, that at Bornite in the western part of the Shungnak district, has been extensively explored. Galena, silver, and a little gold are constituents of some lodes. Float magnetite is common on Iron Mountain near Bornite, but the bedrock source has not been found. In 1944 and 1945, 45 tons of tremolite and 1 ton of chrysotile asbestos were shipped from deposits near Dahl Creek in the Shungnak district. Asbestiform minerals are common in veins 
here and elsewhere north of and within a few miles of the Kobuk River. Nephrite jade, some of gem quality, occurs with the asbestos.

Placer gold was discovered near Shungnak in 1898, on Klery Creek in the central part of the Kiana district in 1909, and much more recently near Purcell Mountain in the Selawik district. Data on production, though incomplete, indicate that the total amount of gold mined was probably somewhat less than 100,000 ounces, about half of which came from the streams near Shungnak and about half from Klery Creek and its tributaries. Jade, used for jewelry and objets d'art, is picked from streams and old tailings piles near Shungnak.

Coal close to the borderline between bituminous and subbituminous in rank occurs in widely scattered localities in Cretaceous rocks near the Kobuk River, but none has been mined except for local use in nearby placer-gold fields.

\section{SEWARD PENINSULA REGION}

The Seward Peninsula region includes the Seward Peninsula and the drainage basins of the Buckland, Inglutalik, Ungalik, and Shaktolik Rivers and Egavik Creek. The region is divided into the Council, Fairhaven, Kougarok, Koyuk, Nome, Port Clarence, and Serpentine districts.

The Seward Peninsula consists mostly of rounded hills and flat divides 500-2,000 feet in altitude; there are also isolated groups of rugged glaciated mountains $20-60$ miles long and 10 miles wide that rise to peaks 2,500-4,700 feet in altitude. A relatively small part of the region consists of interior lowlands and a coastal plain that fringes much of the peninsula.

About half the region is underlain by schist, gneiss, limestone, and slate, which is predominantly of Paleozoic age, but locally, as in the Kigluaik and Bendeleben Mountains, may be as old as Precambrian. Most of the region's lode deposits are in the Paleozoic rocks. Mesozoic rocks broadly divisible into two major groups are abundant in the eastern part of the region. One group consists chiefly of slightly metamorphosed intermediate volcanic rocks, and the other mainly of marine sandstone and shale. The youngest stratified rocks are volcanic ash and basaltic lava flows, in part perhaps as old as late Tertiary but mainly Pleistocene in age. One lava flow near Imuruk Lake is no more than a few centuries old. Most of the pre-Tertiary bedded rocks are complexly deformed. In Early Cretaceous time they were involved in a series of imbricate thrust sheets that were then intricately folded and displaced by normal faults, some with displacement measurable in thousands of feet and intruded by stocks and batholiths that range in age between 100 and 90 million years.

Sand, gravel, and silt thinly mantle bedrock throughout the Seward 
Peninsula region and form deposits as much as 100 feet thick in the lowlands. The Kigluaik, Bendeleben, Darby, and York Mountains and highland areas near the Kiwalik River in the eastern part of the region were glaciated during the Pleistocene Epoch. Ice extended to the Bering Sea from the Kigluaik Mountains at Nome and from the York Mountains in the western part of the peninsula. Only a few small cirque glaciers remain in the highest mountains. The entire peninsula is generally underlain by permafrost.

Metalliferous lodes that were sources of significant amounts of ore, or that contain important resources, include deposits of gold and of tin, tungsten, antimony, and beryllium minerals. Other metals have been discovered, but no major deposits are known although small amounts of copper, lead, and silver, and possibly mercury, have been mined. Total gold production from lodes in the region was no more than a few tens of thousands of ounces; tin lodes in the western part of the Port Clarence district were sources of about 350 tons of tin metal.

The Seward Peninsula has been the source of 30.7 percent, about $6,260,000$ ounces, of the placer gold produced in Alaska. Only the Fairbanks district of the Yukon River region has produced more. Data are not adequate to apportion the total published production for the region among the districts of the Seward Peninsula, but probably half the placer gold reported came from beaches, both modern and Pliocene and Pleistocene, in the Nome district, and the greater part of the rest from stream placers in the Nome, Kougarok, Council, and Fairhaven districts. In much of the peninsula the richest stream placers are near mineralized contacts (possibly thrust faults) between limestone and schist of Paleozoic age. About 2,000 tons of placer tin has been recovered from valleys in the western part of the Seward Peninsula. A little byproduct platinum has come from the eastern part of the region, and about 1,800 units (36,000 pounds) of $\mathrm{WO}_{3}$ (tungstic oxide) from streams and residual material near scheelite-bearing lodes in the Nome area. An additional unknown, but undoubtedly small, amount of scheelite was saved during placer-mining operations for gold in both the eastern and western parts of the peninsula. Some wolframite may have been recovered during tin-mining operations.

Nonmetallic mineral resources include large fluorite deposits near Lost River in the western part of the Port Clarence district. These have recently been extensively explored by a private company and may be in production soon. Tin, tungsten, and possibly beryllium are potential coproducts or byproducts. A little graphite was mined from schist on the north flank of the Kigluaik Mountains in the southern part of the Port Clarence district. In the same general area a few tons of garnet sand was shipped to Nome from a beach of Imuruk Basin.

Lignitic coal occurs in small areas in several parts of the Seward 
Peninsula but has been mined only in the Kugruk valley in the Fairhaven district where 60,000-100,000 tons was mined for local use between 1908 and 1911. Petroleum possibilities of the region are restricted to the continental shelves north and south of the Seward Peninsula.

\section{SOUTHEASTERN ALASKA REGION}

The southeastern Alaska region is the part of Alaska east of longitude $141^{\circ} \mathrm{W}$. It is divided into the Admiralty, Chichagof, Hyder, Juneau, Ketchikan, Kupreanof, Petersburg, and Yakutat districts.

The region, part of the Coast Mountains physiographic province, is essentially mountainous and is composed of a wide belt of rugged islands with summits 2,500-3,500 feet in elevation and a deeply embayed mainland strip with high peaks, many over 10,000 feet in elevation, along the Alaska-Canada boundary. Many of the interisland waterways and major fiords and streams occupy long linear depressions, the most prominent of which is Chatham Strait, a deep trench 4-15 miles wide and at least 200 miles long. In the northwestern part of the district a narrow coastal plain, generally less than 200 feet above sea level and in part covered by the Malaspina Glacier, separates the mountains and the Gulf of Alaska.

Southeastern Alaska was one of the earliest parts of the State to be settled, but the geology of much of it is still not well known. The outcrop pattern of southeastern Alaska is dominated by two northwest-trending belts of Mesozoic sedimentary and volcanic rocks, one adjacent to the Coast Range batholith along the Alaska-British Columbia boundary and the other along the seaward margin of the region. These belts are separated by a band of Paleozoic bedded rocks. Lava flows and tuffs of intermediate to mafiic composition and of Tertiary and Quaternary age are exposed on Admiralty, Kruzof, Kuiu, and Revillagigedo Islands. Mount Edgecumbe on Kruzof Island is a volcano that may have been active in historic time. Tertiary marine and nonmarine clastic rocks underlie part of the coastal plain and foothills near Yakutat. Tertiary nonmarine clastic rocks are exposed on central and southern Admiralty Island.

About a third of the region is made up of plutonic rocks ranging in composition from felsic to ultramafic and in age from Paleozoic to Tertiary. The largest pluton is the Coast Range batholith, a composite structurally complex generally felsic mass exposed along the International Boundary for the length of southeastern Alaska. Smaller plutons, dikes, and sills occur throughout the region. All the preQuaternary bedded rocks have been folded and displaced by faults, some with estimated displacements measurable in many tens of miles.

Extensive Pleistocene glaciation greatly modified the preexisting surface of southeastern. Alaska. Valleys and interisland waterways 
were scoured and deepened, and most preglacial unconsolidated deposits were removed. Remnants of Pleistocene glaciers and ice fields still cover large areas in the high country, and glacial deposits mantle the lower slopes. The Malaspina Glacier in the Yakutat district is one of the largest piedmont ice lobes in the world. In general the region is free of permafrost.

Gold, silver, copper, lead, zinc, platinum-group metals, tungsten, and uranium have been mined commercially from lode sources. Exploratory work, some intensive, has been carried on at prospects potentially valuable for the same metals and for nickel, cobalt, chromite, iron, molybdenum, antimony, and rare-earth elements. Most of the lodes are in metamorphic rocks adjacent to the Coast Range batholith and smaller plutons, though some are confined to the plutons, mainly in marginal facies. Lode production amounted to $7 \frac{1}{2}$ to 8 million ounces of gold (mostly from the Juneau and Chichagof districts), several million ounces of silver (all byproduct or coproduct), about 30 million pounds of copper (from Prince of Wales Island), and more than a quarter of a million pounds of lead (mainly from the Hyder district), as well as small amounts of platinum and palladium (from the Salt Chuck mine in the Ketchikan district), tungsten, zinc, and uranium. Deposits of iron ore near Klukwan in the northern part of the Juneau district and at Port Snettisham in the southern part of the district have been extensively explored since World War II. One or both may soon be developed for the Japanese market.

Compared to the large amount of gold from lode sources in the region, the amount recovered from placer deposits (probably less than 125,000 ounces) is insignificant. Intense alpine glaciation removed most placers that might have been formed as a result of the preglacial erosion of lodes. Most modern streams have extremely steep gradients and discharge into deep fiords, so few gravel deposits are being formed today. Streams near Haines and Juneau in the Juneau district and near Windham Bay in the Petersburg district were the sources of most of the placer gold that has been recovered. Beach sands near Lituya and Yakutat Bays in the Yakutat district were mined for many years, but the total production was probably less than 4,000 ounces. A little platinum occurs with the gold near Lituya Bay.

Nonmetallic mineral resources include large amounts of highcalcium limestone and smaller amounts of marble, gypsum, garnet, and barite, all of which have been produced commercially. Asbestos, fluorite, and mica occurrences are also known but may not be of economic importance.

Sometime before 1929 a little bituminous coal was shipped to Juneau from a mine in Tertiary rocks on central Admiralty Island, but the beds are thin and contain shale partings, so extensive development 
in the forseeable future is unlikely. Although drilling for oil near Yakutat has not been successful, there is great interest in the offshore petroleum potential of the Gulf of Alaska.

\section{YUKON RIVER REGION}

The Yukon River region is the area drained by the Yukon River and its tributaries and by the Unalakleet and Manopiknak Rivers and intermediate streams flowing into Norton Sound and the Bering Sea. The region is divided into 26 districts, described below in alphabetical order.

\section{ANVIK DISTRICT}

The Anvik district comprises the western drainage of the Yukon River between Koyukuk and (and including) the Koserefsky River and the area drained by streams flowing into Norton Sound between Unalakleet and St. Michael Bay.

The district is in the Nulato Hills physiographic province, an area characterized by north- to northeast-trending ridges with crests generally between $2,000-4,000$ feet in altitude separated by structurally controlled valleys with long straight segments. The ridges near Norton Sound are somewhat lower.

The area is underlain largely by Cretaceous and Tertiary (?) volcanic rocks and by mainly Cretaceous clastic marine and nonmarine units of the Koyukuk sedimentary basin. An older Paleozoic and Mesozoic volcanic unit includes intrusive diabase and serpentinite. A large Mesozoic felsic pluton and a line of smaller similar bodies are exposed near the Anvik River. The area southeast of St. Michael is underlain by Tertiary (?) and Quaternary basalt, some of which is so young that primary volcanic features are only slightly modified. The district was not glaciated. It is mainly in a zone of thick to thin permafrost.

The only lode deposit so far discovered in the Anvik district consists of traces of cinnabar and stibnite in hydrothermally altered rhyolite about 40 miles northeast of Marshall. The single commercial placer deposit was on Flat Creek in the southwest corner of the district. An unknown amount of gold, probably less than 25,000 ounces, was mined between 1918 and 1940. Concentrates contained a little cinnabar.

Bituminous coal, generally in thin beds, is a common constituent of some of the Cretaceous rocks. Many years ago small tonnages were mined from several beds exposed at various places along the Yukon River for use in river steamboats. Lignitic coal in Tertiary shale about 10 miles south of Unalakleet has also been mined for local use.

\section{BLACK DISTRICT}

The Black district is bounded on the east by the Alaska-Yukon 
boundary, on the south by the Yukon River, on the west by an arbitrary line between Graphite Point on the Porcupine River and Circle on the Yukon River, and on the north by the divide between the Black and Porcupine Rivers.

The district is mainly in the Porcupine Plateau and Ogilvie Mountains physiographic provinces. The Porcupine Plateau consists generally of rounded ridges averaging 1,500-2,000 feet in altitude, above which isolated summits and a small mountain range project a few hundred feet and into which the principal rivers have cut wide, flat-floored valleys. The Ogilvie Mountains in the southeastern part of the district are somewhat higher; a few peaks reach elevations of over 4,500 feet. The western boundary of the district roughly follows the east edge of the swampy Yukon Flats, most of which is at an altitude of less than 800 feet.

Sedimentary and volcanic rocks that range in age from Precambrian to Cretaceous underlie most of the Black district. Quaternary fluvial deposits and loess floor the major valleys and blanket much of the northwestern part of the district. The area was not glaciated but is in zones of discontinuous and thick to moderately thick permafrost.

The only metallic mineral resource is hematite in a basalt and red-bed unit of the Precambrian Tindir Group in the southeastern part of the district.

Bituminous coal occurs in the Nation River Formation of Devonian age. About 2,000 tons was mined in 1897.

\section{BONNIFIELD DISTRICT}

The Bonnifield district is the area drained by southern tributaries of the Tanana River between and including the Teklanika and Little Delta Rivers.

The district is in the Alaska Range and Tanana-Kuskokwim Lowland physiographic provinces. The highest peaks in this part of the Alaska Range rise over 11,900 feet, but most of the crest is only about 5,000 feet above sea level and is less than 2,500 feet at Broad Pass, which separates major headwater tributaries of the Nenana and Chulitna Rivers. The range is flanked on the north by foothills that are parallel to the main range and slope northward to lowlands generally well below 1,000 feet in altitude.

The Alaska Range is underlain by Precambrian (?) and Paleozoic schists of both sedimentary and igneous origin, quartzite, and marble, all of which were intruded by Mesozoic and Tertiary stocks and dikes of granite, granodiorite, dacite, andesite, and basalt. In the extreme southern part of the district, unmetamorphosed Paleozoic and Mesozoic rocks similar to those in the northern part of the adjacent Cook Inlet-Susitna River region are exposed. Several thousand feet of 
Tertiary clastic rocks, coal, and volcanic rocks crops out along the north flank of the Alaska Range. The Nenana Gravel, a still younger Tertiary formation that commonly is poorly consolidated, covers wide areas between the crest of the Alaska Range and the TananaKuskokwim Lowland. Deposits of several Pleistocene glaciations have been identified, particularly in the Nenana River valley. Except for several ice tongues that extended well beyond the mountains, the lowlands were not glaciated, though thick glaciofluvial deposits and loess derived from them cover the bedrock except for a few isolated groups of hills in which Precambrian or Paleozoic rocks are exposed. The highest mountains are ice covered and are the source of several valley glaciers, two of which are more than 15 miles long. The district is in zones underlain by discontinuous or isolated masses of permafrost.

Lodes in the Bonnifield district are chiefly sulfide disseminations, veins, and lenses in schist and related rocks near the borders of felsic intrusive bodies. Small amounts of gold with subordinate silver and a few tons of antimony ore constituted the lode production. The district has been a small but steady producer of placer gold since 1904; the total output was probably only 45,000 or 50,000 fine ounces. Most of the deposits are stream placers, though gravel on a few benches also was mined. The ultimate source of the gold and accompanying heavy minerals was in quartz veins and mineralized zones in Precambrian (?) and Paleozoic schists, but much of the gold was probably reconcentrated from the Tertiary Nenana Gravel.

The most important mineral resources are extensive deposits of Tertiary coal, mainly subbituminous in rank. Total original resources in beds $2^{1 / 2}$ feet thick or more and beneath less than 1,000 feet of overburden are estimated at 4,789,600,000 short tons. The major current commercial coal mining in Alaska is near Suntrana. Deposits of many nonmetallic mineral commodities and of construction materials, including limestone and perlite, have been investigated, but none have been developed except for road metal and railroad ballast.

\section{CHANDALAR DISTRICT}

The Chandalar district is the area drained by the Chandalar River and its tributaries above the village of Venetie. Its northern boundary is the crest of the Brooks Range.

The district includes parts of the Brooks Range, Porcupine Plateau, and Yukon Flats physiographic provinces and an extension of the Yukon-Tanana Upland (the Hodzana Highland). The Brooks Range slopes southeastward from a crestline 5,000-7,000 feet in altitude to less rugged mountains in the uplands where few summits are above 5,000 feet. Broad valleys of some of the major forks of the Chandalar 
River merge downstream into the Yukon Flats, a swampy area of low relief most of which is at an altitude of less than 1,000 feet.

The bedded rocks are mainly conglomerate and finer clastic sedimentary rocks, limestone and calcareous shale, and mafic volcanic rocks and chert, all of Paleozoic and early Mesozoic age. Basalt flows south of the Chandalar River are of possible Tertiary age. Devonian metamorphic rocks, largely of greenschist facies, form an almost continuous belt, in places as much as 25 miles wide, across the southern part of the district. Mesozoic granitic plutons, some of batholithic dimensions, with well-developed migmatite zones around some borders extend along the southern boundary of the district. Similar plutons intruded sedimentary and metamorphic rocks west and north of Chandalar Lake.

Except for some of the lower areas in the southern part, the district was covered by Pleistocene glaciers, remnants of which are still on some of the high peaks of the Brooks Range. Continuous permafrost underlies most of the district, though it may be absent locally.

Lodes in the Chandalar district contain gold and various sulfides, including stibnite, galena, and sphalerite. The only production, however, was an undetermined but probably small amount of gold, mainly from the Little Squaw mine in the southwestern part of the district. The deposits consist of many steeply dipping auriferous quartz veins in schist cut by gneissic granite. Since 1906 the district has been the source of probably 25,000-30,000 ounces of placer gold, mainly from streams that drain the area around the Little Squaw mine.

No nonmetallic mineral resources (other than material suitable for road metal) or mineral fuels have been found in the district.

\section{CHISANA DISTRICT}

The Chisana district is the Alaskan part of the area drained by the upper White River and its tributaries and by southern tributaries of the Tanana River above and including the Nabesna River.

From south to north it includes the summit areas and north slopes of the Wrangell Mountains, the Nutzotin Mountains and the southeastern part of the Mentasta Mountains (parts of the Alaska Range), and a lake-studded lowland above which rises several isolated patches of hills. The larger rivers all head in glaciers in the high mountains and carry heavy sediment loads. Except for lowlands near the Tanana River, the district was covered by ice during at least two Pleistocene glaciations. Isolated masses of permafrost occur in most of the area. Some of these were penetrated in placer workings.

The Chisana district is underlain mainly by thick sequences of Paleozoic and Mesozoic sedimentary and volcanic rocks cut by several large plutons composed chiefly of granodiorite and quartz diorite of 
Mesozoic age. There are also a few small intrusive bodies of probable Tertiary age. Several isolated remnants of a once more extensive Tertiary gravel cover overlie the older rocks. The Wrangell Lava, a thick sequence of Tertiary and Quaternary flows, caps the high mountains in the southern part of the district. Unconsolidated glacial and fluvial deposits cover most of the lowlands.

Metallic lode deposits are scattered throughout the highland parts of the district, except in areas underlain by the Wrangell Lava. Between 1930 and World War II, production from the Nabesna mine totaled $\$ 1,870,000$ mainly in gold, but with some silver and copper. No production was recorded from any other lode deposit in the district. Of great current interest are several porphyry copper-molybdenum deposits that are being investigated by private enterprise.

Since 1913, placers in the district, almost all in an area of a few square miles near Bonanza Creek, have been the source of about $45,000-50,000$ ounces of gold. The gold was originally derived from small veins in the bedded Paleozoic and Mesozoic rocks, but much of it was reconcentrated from an extensive cover of Tertiary gravel, a remnant of which caps a hill near Bonanza Creek. Native copper, probably largely from amygdules in Triassic lava flows, is a common constituent of placer concentrates, both in the Bonanza Creek area and in other parts of the district.

No potentially valuable nonmetallic mineral resources or mineral fuels have been reported from the Chisana district.

\section{CIRCLE DISTRICT}

The Circle district is the area drained by north-flowing tributaries of the Yukon River from (and including) the Charley River to Circle, Birch Creek above the latitude of Circle, and most of Preacher Creek.

The district includes part of the Yukon-Tanana Upland, the northwest end of the Eagle Trough, and a small tip of the Yukon Flats physiographic provinces. The upland is an area of nearly accordant ridge crests, 3,000-5,000 feet in altitude, above which domes and isolated summits, especially in the southeastern part of the district, rise as much as 1,400 feet. The gross pattern of the entrenched complex drainage system probably was determined by faults and by jointing in crystalline rocks. The Eagle Trough, also called the Tintina Valley, is a lower area that extends northwestward from the Alaska-Yukon boundary parallel to the Yukon River, from which it is separated by a line of low hills. At its northwest end, about 25 miles south of Circle, it merges with the Yukon Flats, a lake-studded area less than 1,000 feet above sea level.

The upland area is a complex metamorphic terrane of Precambrian (?) and Paleozoic gneiss, schist, and crystalline limestone that was 
invaded by mainly Mesozoic felsic, mafic, and ultramafic intrusive bodies, the largest of which is the Charley River batholith, which underlies much of the southeastern part of the district. Upper Cretaceous and Tertiary continental rocks, including a few thin lignite or subbituminous coal beds, floor the Eagle Trough. Between the Eagle Trough and the Yukon River bedrock is Paleozoic and Mesozoic unmetamorphosed clastic, carbonate, and volcanic rocks. Quaternary deposits include alluvium and terrace gravels along streams, loess in many places, and glacial deposits near some of the highest mountains, the only parts of the area that were covered by Pleistocene ice. The highland parts of the district are in a zone of discontinuous permafrost, and the lowlands in zones characterized by generally continuous permafrost.

No productive lodes have been found in the Circle district, though a few prospects have been explored for copper, gold, or lead. Since 1894 nearly 750,000 ounces of placer gold (about 3.6 percent of the total for the state) has been mined from streams in the Circle district. The bulk of this came from Mammoth and Deadwood Creeks and their tributaries near Miller House and from Coal and Woodchopper Creeks, which are tributaries of the Yukon River. Near Miller House the heavy minerals in the placers were derived from mineralized veins in the metamorphic rocks and younger felsic plutons. When the price of tin and tungsten was high, small amounts of byproduct cassiterite and wolframite were separated from the rest of the concentrates. Some of the gold in the placers of Coal and Woodchopper Creeks was probably reconcentrated from Tertiary and continental rocks.

No nonmetallic mineral resources other than material suitable for road metal and similar uses have been found in the district. As far as it is known, there has been no attempt to utilize the coal in the Eagle Trough.

\section{DELTA RIVER DISTRICT}

The Delta River district is the area drained by northward-flowing tributaries of the Tanana River between and including the Johnson River on the east and Delta Creek on the west.

The district is mainly in the Alaska Range, where many peaks are more than 8,000 feet and a few are more than 13,000 feet in altitude. The drainage divide between the Delta and Gulkana Rivers is about 35 miles south of the highest peaks. From the crest of the Alaska Range the land slopes northward to the flats of the Tanana-Kuskokwim Lowland where elevations are less than 1,500 feet.

The Denali fault, one of the major tectonic elements of Alaska and adjoining parts of Canada, crosses the district just south of the crest of the Alaska Range. The area north of the fault is underlain mostly by Precambrian and Paleozoic metamorphosed rocks, largely of sedimen- 
tary origin. They were intruded, mainly in the Mesozoic Era, by granitic dikes, sills, and plutons, some of batholithic dimensions. South of the fault a few exposures of metamorphic rocks have been reported, but most of the area is underlain by Paleozoic and Mesozoic volcanic and clastic rocks with discontinuous interbedded Paleozoic limestone units. Dikes; sills, and other intrusive bodies that range in composition from felsic to ultramafic and are of Paleozoic and Mesozoic age intruded the bedded rocks. Tertiary nonmarine rocks, some coal bearing, cover large areas north of the mountain front and smaller areas in the Alaska Range. The mountains were glaciated several times during the Pleistocene. Large tongues of ice advanced down the valley of the Delta River nearly to its confluence with the Tanana. Much of the high country is still ice covered, and large valley glaciers extend down to elevations well below 3,000 feet. Glacial and glaciofluvial deposits cover most of the district, and loess derived from periglacial flood plains blankets much of the Tanana valley. Most of the district is in a zone of discontinuous permafrost; some areas in the TananaKuskokwim Lowland are underlain by moderately thick to thin permafrost.

Except for a few tons of ore that was mined, but not shipped, from a molybdenite deposit about 15 miles north of Mount Hayes, there has been no lode mining in the Delta River district, though occurrences of sulfide minerals, most associated with ultramafic or volcanic rocks south of the Denali fault, have been found. Some of these deposits and a quartz vein in schist a few miles north of the Denali fault carry a little gold, but not enough to be of current economic interest. Total placergold production was not enough to be of current economic interest. Total placer-gold production was not much more than 1,000 ounces and was mainly from Rainy Creek south of the Denali fault where some of the gold was probably reconcentrated from glacial deposits.

The nonmetallic mineral resources of the district consist of asbestos associated with serpentinite near the headwaters of the Delta River and granite in a quarry east of the lower Gerstle River.

The Jarvis Creek coal field contains resources of high-ash subbituminous coal in thin beds estimated at 76,500,000 short tons. A few thousand tons were mined in 1958 and in 1971-72.

\section{EAGLE DISTRICT}

The Eagle district is the area drained by the southern tributaries of the Yukon River between (but excluding) the Charley River on the west and the Alaska-Yukon boundary on the east.

The district includes parts of the Eagle Trough and Yukon-Tanana Upland physiographic provinces. The upland is an area of even-topped ridges, 3,000-5,000 feet in elevation, separated by generally narrow valleys and, along the southern boundary of the district, surmounted 
by isolated mountains that rise as much as 1,000 feet above the general level. The Eagle Trough, also called the Tintina Valley, is southwest of and parallel to the Yukon River, from which it is separated by discontinuous low hills. Ridges within the trough are 2,000-2,500 feet in altitude and are separated by valleys $1,000-1,500$ feet deep.

The upland areas are mainly Precambrian (?) and Paleozoic metamorphic rocks that were invaded by Mesozoic and, to a lesser extent, Paleozoic and Tertiary plutons, dikes, and sills of felsic, mafic, and ultramafic composition. The Eagle Trough, which generally follows the Tintina fault zone, a major tectonic element in this part of Alaska and adjoining Canada, is underlain by Upper Cretaceous and Tertiary continental conglomerate, finer grained clastic rocks, and thin beds of lignite or subbituminous coal. Between the Tintina fault zone and the Yukon River, the pre-Late Cretaceous rocks are sedimentary and volcanic members of the Tindir Group of Precambrian age, and clastic and carbonate formations of Paleozoic and Mesozoic age. Quaternary deposits in the district are mainly alluvium and terrace deposits along streams. Except for cirque glaciers on a mountain in its southern part, the district was ice free during the Pleistocene Epoch. The area is mainly in a zone of discontinuous permafrost.

No workable lodes have been found in the Eagle district although sulfide-bearing material was reported from Eagle Bluff near the mouth of Mission Creek. In 1968, sulfide-bearing samples were collected during a geochemical reconnaissance of part of the Seventymile River area, but nothing of immediate commercial interest was discovered.

Placer-gold deposits, first discovered in about 1895, have been mined consistently since 1900 , and have yielded a total of somewhat less than 50,000 ounces, mainly from tributaries of the Seventymile River. The ultimate sources of most of the gold were veins in metamorphic rocks and mineralized fault zones, but much of the gold was immediately derived from auriferous conglomerate and associated clastic rocks in the Eagle Trough. Platinum, either as discrete grains or alloyed with gold, is a constituent of some placer concentrates.

Asbestos, associated with serpentinized ultramafic rocks, is the only nonmetallic mineral resource other than sand and gravel, in the district. Although none has been mined, there has been considerable recent interest in several of the deposits.

A little coal was mined from beds in the Eagle Trough in about 1900.

\section{FAIRBANKS DISTRICT}

The Fairbanks district is the area drained by the Chatanika River and northern tributaries of the Tanana River from Minto to and including Shaw Creek. 
The district is within the Yukon-Tanana Upland except for isolated areas along its southwest border that are in the Tanana-Kuskokwim Lowland, and it consists of marshy flats along the lower courses of major tributaries of the Tanana River. Most of the district is a dissected plateau 2,000-4,500 feet in altitude that rises gently from west to east and is characterized by many wide valleys separated by broad rolling divides surmounted by rounded domes and a few mountainous areas that rise several hundred feet higher.

The oldest rocks in the Fairbanks district are a group of schists, crystalline limestone, quartzite, amphibolite, and gneiss of Precambrian and early Paleozoic age. These rocks were intruded by mainly Mesozoic plutons and dikes, most of which are granodiorite, quartz diorite, or porphyritic granite and quartz monzonite. Nearly all the domes and mountains that rise above the general upland surface are underlain by such rocks. Many serpentinized ultramafic bodies are in the upper valley of the Salcha River in the eastern part of the district. Except for a few local cirque glaciers on the highest mountains, the district was not ice covered, but the Quaternary history of this periglacial area is complex. The uplands are generally covered by a blanket of loess derived (and still being derived) from the proglacial flood plains of streams issuing from the Alaska Range many miles south of the Tanana River. Loess mixed with locally derived clastic material and vegetation chokes valleys and forms the frozen muck that overlies most of the placer-gold deposits. Frozen tissues and skeletal remains of Pleistocene mammals are common in this material.

Most of the lodes in the Fairbanks district are concentrated in an area within about 25 miles of Fairbanks, though a few, none of which have been productive, have been found elsewhere. Total lode production was about 239,250 ounces of gold, 39,000 ounces of silver, 2,500-3,000 tons of antimony ore, and scheelite ore and concentrates containing several thousand units of WO3. In the vicinity of Fairbanks, gold lodes are near granitic plutons at Pedro and Gilmore domes northeast of Fairbanks and at Ester dome (where the pluton has not yet been unroofed) west of the city. The tungsten deposits (predominantly scheelite) are principally in the Gilmore dome area. Lodes in other parts of the district appear to be in similar geologic settings. The precious-metal lodes are commonly in fissure veins, composed mainly of quartz, that cut schist, usually near contacts with felsic intrusive rocks. The antimony deposits occupy the same lodes as the economically more important gold deposits. Sulfide and sulfosalt minerals are constitutents of most of the veins. The tungsten deposits are in limestone lenses that were largely replaced by silicate minerals, in granitic and pegmatitic dikes, and in auriferous quartz veins.

The Fairbanks district has produced more placer gold than any other 
in the state, exceeding the total production of the Seward Peninsula region by well over a million ounces. About 7,650,000 ounces has been produced since 1902, when gold was discovered on Pedro Creek. This amount represents 37.2 percent of the total recorded Alaskan placergold production. Large dredges were first used near Fairbanks in 1928. Before that time high-grade deposits were worked mainly by drift mining and scraper plants after permafrost had been thawed with steam. Some of the deposits were very rich; for example, the average tenor of the gravel mined in 1908 was about $\$ 5.60$ (gold at $\$ 20.67$ per ounce) per cubic yard. The dredges worked lean ground that had been thawed with cold water and reworked areas that had been mined by other methods. Placer mining in parts of the district not close to Fairbanks accounted for between 100,000 and 200,000 ounces of gold.

The heavy minerals in the placers were probably derived from local lode deposits, as valuable placers were found only where lodes containing the same minerals were mined or prospected. Most of the placers in the district were stream placers that had been buried by more recent alluvium and loess that choked creek valleys; a few deposits on buried bedrock benches, however, were found during drift mining.

The nonmetallic mineral resources (other than material used for road metal, railway ballast, and decorative stonework) in the district consist of small bodies of limestone and deposits of clay possibly suitable for rough ceramic uses. None have been developed. No occurrences of mineral fuels are known in the district.

\section{FORTYMILE DISTRICT}

The Fortymile district comprises the Alaskan part of the Fortymile River drainage basin, the area drained by streams flowing southwest into the Tanana and Chisana Rivers and Scottie Creek from Tanacross to the Alaska-Yukon boundary, and the Alaskan parts of the basins of western tributaries of the Sixtymile and Ladue Rivers.

The district is almost entirely within the Yukon-Tanana Upland physiographic province and consists of discontinuous groups of mountains that rise a few hundred feet above a fairly uniform plateau that is $3,000-5,000$ feet above sea level, except where interrupted by the valleys of the Fortymile River and its forks and a few other streams.

Most of the district is a complex terrane of Precambrian(?) and Paleozoic gneiss and schist and minor crystalline limestone that was intruded at intervals during Paleozoic, Mesozoic, and Tertiary time by felsic, mafic, and ultramafic rocks. Some of the felsic intrusive bodies, particularly those in the western and northern parts of the district, are Mesozoic batholiths of great areal extent. Ultramafic bodies, wholly or partially serpentinized, crop out in many parts of the Fortymile and neighboring districts and are of Mesozoic age. A small syenite pluton, 
dikes, sills, and other small intrusive masses of granite porphyry, and mafic and felsic volcanic rocks were emplaced during the Cenozoic Era. Detrital Tertiary rocks were deposited in local basins where they are associated with volcanic and volcaniclastic material.

The Yukon-Tanana Upland was not glaciated (except for the summits of some of the highest mountains) but loess, derived largely from proglacial floodplains to the south, mantles much of the area. The district is in a zone of discontinuous permafrost. Much of the ground that was placer mined was permanently frozen.

Only a few lodes have been found in the Fortymile district; a little gold was mined from one near Chicken. The lodes consists of quartz veins in metamorphic rocks or, less commonly, contact-metamorphic deposits carrying gold, silver, lead, copper, zinc, antimony, and iron.

The Fortymile is one of the oldest placer districts in Alaska. The discovery of gold in the late 1880's was followed in 1893 by a stampede during which claims were staked in most of the valleys. Placers have yielded about 470,000 ounces of gold, 2 percent of the total placer-gold production from Alaska. The source of the gold was abundant small mineralized veins in metamorphic rocks near contacts with felsic intrusive bodies. Heavy minerals in concentrates include gold, scheelite, cassiterite, and various sulfide minerals, but none except gold have been recovered commercially. Both bench and stream placers were mined, with the bulk of the gold coming from bench deposits near Chicken and from the Fortymile River and its tributaries where dredges were used from 1906 until the end of the 1967 season.

Recently there has been much interest in newly discovered asbestos deposits in serpentinized ultramafic bodies, but activity has not progressed beyond the prospecting stage. The only mineral fuel resource in the district is subbituminous coal at Chicken where a bed at least 22 feet thick, but of small areal extent, was once mined for local use.

\section{GOODPASTER DISTRICT}

The Goodpaster district is the area drained by northern tributaries of the Tanana River between Big Delta and Tanacross. Physiographically and geologically it is an extension of the adjoining Fortymile district.

The only lode production consisted of a small quantity of gold ore mined from free gold- and sulfide-bearing quartz veins near Tibbs Creek in the northern part of the district where antimony and molybdenum minerals have also been found. There has been prospecting for placer gold in several parts of the district, and a few minor discoveries were reported, but the total production was so small that it was never reported separately from that of neighboring districts. No nonmetallic or mineral-fuel resources have been discovered. 


\section{HOT SPRINGS DISTRICT}

The Hot Springs district is the area drained by southern tributaries of the Yukon River between Kallands and (but not including) Fish Creek and by tributaries of the Tanana River as far upstream as Dugan Creek.

The northern part of the district is in the Yukon-Tanana Upland and the southern part mainly in the Tanana-Kuskokwim Lowland. The northern part consists of several even-topped ridges 1,600-2,500 feet in altitude and a few more rugged isolated mountains with summits below 5,000 feet. Wide valleys merge with the Tanana-Kuskokwim Lowland, much of which is less than 500 feet above sea level. The northeast end of the Kuskokwim Mountains is in the extreme southern part of the district and is made up of groups of hills $2,000-3,200$ feet in altitude that are separated by broad valleys that slope northward and northeastward to the lowland.

North of the Tanana River, Paleozoic chert, limestone, and clastic rocks, many somewhat sheared and metamorphosed, are the oldest units. They are overlain by Cretaceous argillaceous rocks, graywacke, and sandstone that were metamorphosed in much of the area to slate, phyllite, and quartzite. The youngest consolidated bedded rocks are Tertiary continental conglomeratic beds in a small area near the Yukon River about 20 miles upstream from Tanana. Bodies of mafic rocks, now largely serpentinized, intruded the bedded rocks near Tofty. Felsic plutons of probable Tertiary age make up several of the mountains and high parts of ridges. South of the Tanana and Yukon Rivers clastic, carbonate, and volcanic rocks, of Paleozoic, Mesozoic, and Tertiary ages, were intruded by at least two granitic plutons. Nearly all major stream valleys and the Tanana-Kuskokwim Lowland within the district are covered by Quaternary glaciofluvial material derived from the Alaska Range to the south, alluvium of local origin, and loess. Much of this material is perennially frozen and has a high content of organic material. No part of the Hot Springs district has been glaciated.

None of the few lode deposits in the district has been productive. A shear zone on the summit of Manley Hot Springs Dome contains argentiferous galena and minor amounts of gold, various sulfide minerals and their alteration products, and erythrite, a cobalt mineral. Grains of chromite disseminated in a serpentinized mafic rock were found on Serpentine Ridge near Tofty.

Since the discovery of gold near Eureka in 1898, placers in the Hot Springs district have produced about 450,000 ounces of gold (about 2.2 percent of the total placer-gold production of Alaska) and several hundred tons of cassiterite concentrates from gold mines near Tofty. Definite sources of the valuable heavy minerals in the placers have not 
been found. Because of thick frozen silt and moss cover, data on bedrock in much of the district can come only from drill holes, prospect shafts, or ephemeral exposures in placer mines. Chromite, a major constituent of the concentrates from some creeks, probably came from serpentinized ultramafic or mafic rocks such as are exposed on Serpentine Ridge. No valuable placer deposits have been found in the part of the district south of the Tanana and Yukon Rivers.

Except for material suitable for road metal, valuable nonmetallic mineral deposits have not been found in the district. Subbituminous coal occurs in Tertiary continental rocks near the Yukon River, but not in currently minable amounts.

\section{HUGHES DISTRICT}

The Hughes district includes the area drained by the Koyukuk River and its tributaries below the Kanuti River and by northern tributaries of the Yukon River between Koyukuk and Melozi.

The central part of the district is made up of the Koyukuk Flats, a swampy, lake-studded lowland generally less than 200 feet above sea level through which the Koyukuk River and its tributaries meander. Low mountains and uplands fringe the lowlands. The crests of the hills are commonly 2,000-3,000 feet in altitude though the summit, Indian Mountain, east of Hughes, is more than 4,200 feet above sea level, and several broad passes and ill-defined drainage divides are below 1,000 feet.

The mountains surrounding the Koyukuk Flats are underlain mainly by Jurassic and Cretaceous marine and nonmarine clastic and volcanic rocks that were intruded by large granitic and monzonitic plutons and small bodies of latitic hypabyssal rock of Late Cretaceous age. The Koyukuk Flats are underlain by thick alluvial and glaciofluvial deposits covered by eolian deposits, including large areas of active sand dunes. Broad alluviated valleys of the major rivers merge downstream into the flats. Pleistocene ice from the Brooks Range covered the northern part of the district and parts of the Zane Hills, Purcell Mountains, and Indian Mountains, but, in general, the area was not glaciated and there are no modern glaciers. Except for the Zane Hills, where there are unfrozen areas, the district is in zones of continuous permafrost.

The only lode deposits in the district are near Indian Mountain where small amounts of zinc and copper sulfides occur in highly altered fine-grained pyritiferous intrusive rocks, metavolcanic rocks, and aplite near the borders of a pluton. Molybdenite has been found in bedrock exposed during placer mining on Indian River. Near the head of Utopia Creek, massive barite boulders, for which no bedrock source has been determined, contain tetrahedrite, galena, and sphalerite. 
Near a slough of the Koyukuk River a float block of altered silicified rock containing disseminated cerrusite, galena, and malachite and 3 ounces of silver per ton was found. This material, numerous dikes, and a zone of thermally metamorphosed andesite suggest that a pluton may underlie the area at shallow depth.

Placer gold was discovered in about 1890 on bars of the Koyukuk River. Most later mining, however, was near Hogatza and on streams that drain Indian Mountain east of Hughes. No accurate estimate of the amount of gold produced can be made, but it must have been several times the 8,500 ounces definitely allocatable to the Hughes district on the basis of published data. A large dredge has been operated at Hogatza since 1957; the owner, however, has released no pertinent information other than the number of employees.

A thin bituminous coal bed in Upper Cretaceous clastic rocks exposed along the Yukon River may have provided a few tons of fuel for river boats in about 1900. Possible resources of minable coal in the district are probably small. Cretaceous sedimentary rocks in the Koyukuk Basin have been investigated as a possible source of petroleum, but the current outlook is not promising because igneous bodies are more common than had been anticipated, and no large uncomplicated structures have been discovered. No deposits of potentially valuable nonmetallic mineral commodities have been found in the district.

\section{IDITAROD DISTRICT}

The Iditarod district comprises the areas drained by eastern tributaries of the Yukon River between and including Paimut and Shageluk Sloughs, by southern tributaries of the Innoko River between Holikachuk and Dishkakat, and by tributaries of the Innoko below Holikachuk.

The district is in the Kuskokwim Mountains and YukonKuskokwim Lowlands physiographic provinces. The southeastern part of the area consists of rounded northeast-trending ridges generally less than 1,500 feet in altitude that are surmounted by a few isolated rugged mountains, most of which are on the YukonKuskokwim divide and all of which are lower than 3,000 feet. Major valleys are generally straight and, except in headwater sections, broad and swampy. The rest of the district is low (at most only a few hundred feet above sea level), lake speckled, swampy, and crossed by widely meandering tributaries and sloughs of the Yukon River.

The upland part of the district is underlain mainly by Cretaceous shale (now metamorphosed in places to slate) and coarser clastic rocks and basalt, by an upper Paleozoic and lower Mesozoic clastic unit, and by older Paleozoic metamorphic rocks. Tertiary mafic and felsic rocks form sills and other small intrusive bodies. Near Flat, small Tertiary 
monzonite stocks, possibly apophyses of an incompletely unroofed pluton, metamorphosed the surrounding Cretaceous clastic rocks. Much of the highland area is mantled by a blanket of weathered residual material, colluvium, and silt. The valleys and lowlands near the Yukon and Innoko Rivers are covered by thick deposits of alluvium. The mountains are not high enough for Pleistocene cirques to have formed, and ice from glaciers in adjoining areas did not invade the district. Most of the district is in a zone of moderately thick to thin permafrost except the lower Iditarod and Innoko valleys which are underlain by isolated masses of perennially frozen ground rather than continuous permafrost.

Lodes in the Iditarod district contain cinnabar, stibnite, gold, silver, and lead and zinc minerals. The DeCourcy Mountain mine in the southern part of the district produced more than 1,200 flasks of mercury and is the major Alaskan mercury mine outside the Kuskokwim River region. Near Flat many quartz and calcite veins carrying stibnite, cinnabar, other sulfide minerals, and gold occur in two small monzonite stocks and in contact-metamorphic aureoles in the surrounding Cretaceous bedded rocks. Most of the veins are less than 3 feet thick. Many have been explored on a small scale, and an unrecorded amount of gold is said to have been mined from some of them in the early years of activity in the area. One mine that was operated in the 1920's and 1930's had a total reported production of 528 tons of ore from which 2,706 ounces of gold, 2,620 ounces of silver, 9,336 pounds of lead, and 653 pounds of zinc were recovered.

Placer gold was discovered near Flat late in 1908, setting off a stampede in 1910. In 1912 more than 130,000 ounces of gold was mined from the immediate area. Total production from the Iditarod district was more than 1,325,000 ounces, or over 6 percent of the placer gold produced in Alaska; almost all was from within 9 miles of Flat. The source of the gold is veins in two monzonite stocks and their surrounding contact aureoles. Cinnabar is a common constituent of the concentrates from almost every creek. Some may have been saved and retorted to produce quicksilver for local use.

No valuable nonmetallic mineral resources are known in the district. The only organic-fuel occurrences reported are in Cretaceous rocks between Iditarod and Flat where sheared anthracite coal is exposed in several places. There has been no significant development of this resource.

\section{INNOKO DISTRICT}

The Innoko district is, excepting the Poorman area, the area drained by the Innoko River and its tributaries above Dishkakat.

Most of the district is in the Kuskokwim Mountains physiographic province, but the northwestern and western parts are low country that 
is continuous with the Koyukuk Flats and the Yukon-Kuskokwim Lowland. The mountain area is a rolling upland generally less than 2,000 feet in elevation above which rise several isolated rugged masses with summits from 3,500 to more than 4,200 feet above sea level. The lowlands and part of the upper Innoko valley are swampy and dotted with small lakes of probable thermokarst origin.

The uplands are underlain mainly by Cretaceous clastic rocks, some of which now exhibit slaty cleavage. Older rocks include Paleozoic and Mesozoic metasedimentary and metavolcanic rocks and chert. Cretaceous and Tertiary igneous rocks include basaltic lava flows and tuffs, dikes and other small intrusive bodies ranging in composition from rhyolite to pyroxenite, and monzonite and quartz monzonite plutons that in places metamorphosed the enclosing rocks to hornfels. The lowlands and major valley floors are covered by surficial deposits that are mainly of nonglacial origin. Silt, largely wind deposited, mantles many of the slopes, and colluvium and residual weathered material hide bedrock in much of the upland part of the district. The higher isolated mountain groups supported Pleistocene cirque glaciers, but most of the district was ice free. Permafrost, discontinuous beneath parts of the Innoko and Dishna valleys and some of the higher hills and mountains, underlies the area.

Lodes in the Innoko district contain stibnite, cinnabar, and gold. The only production was a little gold from a quartz vein along the hanging wall of a felsic dike about 10 miles southeast of Ophir. Similar lodes are probably hidden beneath the overburden.

Placer mining centered around Ganes and Cripple Creeks in the eastern part of the district and Boob Creek near the Dishna River. Gold was discovered first on Ganes Creek in 1906 and a few years later in the other two areas. Production for the district has been about 550,000 ounces, or 2.7 percent of the total for the State. A small amount of platinum was recovered from Boob Creek in the course of gold mining. In the Ganes Creek area most of the deposits are on buried bedrock benches, although stream placers were also mined. The gold came from small gold-bearing quartz veins and, probably, mineralized zones with little or no quartz near dacite and andesite dikes that closely follow slaty cleavage. Veinlets in and around plutons were the probable sources near Cripple and Boob Creeks.

No nonmetallic or mineral-fuels resources have been found in the Innoko district.

\section{KAIYUH DISTRICT}

The Kaiyuh district is the area drained by streams flowing west and north into the Yukon River from Shageluk Slough to (but excluding) the Yuko (Yuki) River and by streams flowing south into the Innoko River between Holikachuk and Dishkakat. 
The district includes most of the Kaiyuh Hills physiographic province and large low-lying areas continuous with the Koyukuk Flats and Yukon-Kuskokwim Lowland. The Kaiyuh Hills is an isolated range of northeast-trending mountains generally from 1,000 to 2,250 feet in elevation with several summits that are a few hundred feet higher. The range is broken into three segments by broad valleys separated at their heads by divides only a few hundred feet above sea level. About two-thirds of the district is made up of low swampy areas with many lakes, sloughs of the Yukon and Innoko Rivers, and sluggish streams following tortuous courses.

The Kaiyuh Hills are made up mainly of Precambrian or lower Paleozoic schist, quartzite, and recrystallized limestone, and younger upper Paleozoic and (or) lower Mesozoic metamorphosed mafic extrusive and intrusive rocks with some interbedded chert, limestone, and graywacke. Cretaceous clastic rocks similary to those in the Koyukuk sedimentary basin to the north and west form low hills east of the lower Khotol River and an isolated peak just south of the Yukon River between Nulato and Galena. Several granitic plutons of Mesozoic or Tertiary age intruded the older rocks. The highlands are generally covered by frost-rived rubble, colluvium, and silt (some of which is probably loess) and are generally below tree line, so outcrops are scarce. The lowlands are covered with thick alluvium. The district was not glaciated. Except for part of the Innoko valley where permafrost is discontinuous, the area is in a zone generally underlain by moderately thick to thin frozen ground.

Lode deposits have been found in two places in the Kaiyuh district. In the northern part of the district near the crest of the Kaiyuh Hills argentiferous galena veins in schist were the source of 100-200 tons of silver-lead ore. In the southern part of the district a molybdenitebearing quartz vein in rhyolite porphyry was explored in 1942 , but no ore was mined.

The only placer mining in the district was at Camp Creek at the site of the abandoned village of Tlatskokot where an unknown, but undoubtedly small, amount of gold was recovered immediately after World War II.

No nonmetallic or mineral-fuels resources have been discovered in the district.

\section{KANTISHNA DISTRICT}

The Kantishna district is the area drained by the Kantishna River and southern tributaries of the Tanana River between the Kantishna and the Zitziana Rivers.

The southern boundary of the district follows the crest of the Alaska Range. To the north the mountains drop off abruptly to the Tanana- 
Kuskokwim Lowland, a gently northward-sloping lake-dotted area generally less than 2,000 feet above sea level. The Kantishna Hills, a group of rugged mountains less than 5,000 feet in altitude, extend about 20 miles north of the range.

North of the Denali fault zone, which is about 6 miles north and northwest of the crest of the Alaska Range and is hidden beneath the Muldrow Glacier for 17 miles, the geology is an extension of that of the adjacent Bonnifield district. In the Kantishna district, however, the distribution of Tertiary rocks is much more restricted, and most of the Mesozoic felsic intrusive bodies are much larger than in the Bonnifield district. The rocks south of the Denali fault zone are generally Mesozoic sedimentary rocks. They were intruded by a large granitic batholith near Mount McKinley and by possibly related stocks. The lowlands north of the mountains are covered by Quaternary unconsolidated glaciofluvial and eolian deposits. The Alaska Range and part of the piedmont were covered by ice during several Pleistocene glaciations, but the lowlands were ice free. Today most of the high country is glacier covered with spectacular ice tongues. Longest is the Muldrow Glacier, extending down to elevations of less than 4,000 feet. The mountains and the Kantishna Hills are in a zone of discontinuous permafrost; the lowlands are largely underlain by moderately thick to thin continuous permafrost, though in areas of coarse-grained deposits only isolated masses are perennially frozen.

Lodes in the Kantishna district have yielded small amounts of gold, silver, antimony, and lead ore. Most of the lodes are quartz veins in schistose rocks, and these veins carry gold, argentiferous galena, and other sulfide minerals, but one group of prospects from which there has been no production is in contact-metamorphic deposits of argentiferous galena and other sul!des in recrystallized limestone. About 1,000 tons of argentiferous galena ore averaging from $\$ 150$ to more than $\$ 250$ a ton in silver and carrying a little gold and an unreported amount of lead was taken from mines in the Kantishna Hills. In the same general area about 3,500 tons of stibnite ore was mined from deposits at Stampede and on Slate Creek. Cinnabar is a major constituent of one nonproductive lode high in the mountains.

In 1905 , gold in paying quantities was found in several creeks in the Kantishna Hills. Mining continued for many years with no more than 4,000 ounces being recovered in any single year. Total production was between 45,000 and 50,000 ounces. The heavy minerals in the placers came from nearby lodes.

No occurrences of nonmetallic mineral resources other than material for road metal have been reported. There are coal beds in some of the Tertiary rocks in the eastern part of the district, but no one has mined them. 


\section{KOYUKUK DISTRICT}

The Koyukuk district is the area drained by the Koyukuk River and its tributaries above and including the Kanuti River.

Areally one of the largest in the Yukon River region, the district extends from the Brooks Range southward to extensions of the Yukon-Tanana Upland. Between these highlands are lower uplands and broad poorly drained lowlands, of which the Kanuti Flats in the southern part of the district is the largest. The crest of the Brooks Range, which reaches elevations of 6,000 to more than 7,000 feet, is broken by several passes, the lowest of which is below 2,200 feet. The Kanuti Flats and similar terrain near the confluence of the South Fork of the Koyukuk with the main river are generally less than 600 feet above sea level, though a few isolated hills are somewhat higher. The southern and southeastern boundaries of the district follow the crests of the Ray Mountains and the Hodzana Highlands, with summit elevations generally between 3,000 and 4,000 feet, though there are several higher peaks.

Geologically the northern two-thirds of the district is a westward extension of the Chandalar district with bedded rocks of Paleozoic age underlying much of the area, and a belt of metamorphic rocks, mainly of greenschist facies and of Devonian age, extending across the southern foothills of the Brooks Range. Except near Big Lake and west of the head of Malamute River, this part of the Koyukuk district was not invaded by large granitic plutons, though dikes are fairly common in some places. In the Ray Mountains and the highlands at the head of the Dall River, however, large late Cretaceous quartz monzonite plutons and smaller bodies of hypabyssal rocks intruded metasedimentary rocks. The Koyukuk basin is underlain by Cretaceous marine graywacke and mudstone and nonmarine clastic and tuffaceous beds. Felsic flows and volcaniclastic rocks overlie the older units. Pleistocene ice from the Brooks Range and from cirque glaciers in the Ray Mountains covered much of the higher parts of the district. Modern glaciers are restricted to cirques in the highest parts of the Brooks Range. The lowlands are floored by Pleistocene glaciofluvial and Holocene flood-plain deposits. Most of the area is in zones of continuous permafrost, except for some of the highlands and a few valleys where permafrost is discontinuous.

Lodes containing gold and silver, and antimony, copper, lead, and manganese minerals have been discovered in the part of the district underlain by metamorphic rocks, but no lode mines have been developed. The lode deposits are mainly quartz and quartz-stibnite veins in phyllite and schist and galena in crystalline limestone.

Placer gold was found on bars of the Koyukuk River and on some of 
its forks between 1885 and 1890 , but the first major discoveries were in creeks near Wiseman in about 1900 . Total production from the district was probably not less than 270,000 or more than 295,000 ounces of gold, more than 85 percent of which came from streams in a small area north of Wiseman. Other mining was near Wild Lake and on tributaries of the John and Middle Fork of the Koyukuk Rivers. Heavy minerals, which include native silver and copper and stibnite, were derived from auriferous quartz and quartz-stibnite veins, many of which were uncovered during mining operations. A total of about 5 tons of stibnite was sluiced from creek gravels and weathered material above a lode in the bottom of one creek during World War II.

No nonmetallic mineral resources other than sand and gravel have been found in the Koyukuk district. Coal beds in Upper Cretaceous rocks have not been sufficiently investigated to determine their economic potential.

\section{MARSHALL DISTRICT}

The Marshall district is the area drained by the Yukon River and its tributaries below Paimiut Slough and by streams flowing into the Bering Sea between Hazen and St. Michael Bays. In addition the district includes a small area northwest of the Yukon River between (but excluding) the Koserefsky River and the lower end of Paimiut Slough.

The district includes the northern half of the Yukon-Kuskokwim Lowland and the southwest end of the Nulato Hills physiographic provinces. The part of the district in the Yukon-Kuskokwim Lowland is mainly the delta and old flood plains of the Yukon River, a low marshy area studded with lakes and traversed by sluggish streams. Small but rugged mountain masses protrude through the alluvial cover, reaching elevations greater than 2,000 feet. The southwest end of the Nulato Hills consists of a series of northeast-trending ridges with crest elevations generally between 1,000 and 2,000 feet.

Mesozoic, mainly Cretaceous, marine and nonmarine clastic rocks and andesitic volcanic and volcaniclastic rocks underlie most of the Marshall district. Volcanic and sedimentary rocks of Carboniferous (?) to Cretaceous age are exposed in the hills north of the Yukon River east of Marshall. Younger Cretaceous felsic bodies, including a granodiorite batholith, intruded some of the bedded rocks and thermally metamorphosed them near some contacts. The youngest consolidated rocks in the district are horizontal Quaternary basalt flows and associated fragmental rocks and their source cones, some of which are almost unmodified by erosion. These mafic volcanic rocks are exposed in a large area on Stuart Island and on the mainland near St. Michael and in several smaller areas in the Yukon Delta. Quaternary 
alluvial, deltaic, and marine sand and silt make up most of the Yukon Delta and floor most rivers valleys and a large, low swampy area north of Marshall. Deposits in the Askinuk Mountains in the Yukon Delta record small Pleistocene cirque glaciers; the rest of the district was ice free. The entire area is in a zone generally underlain by moderately thick to thin permafrost.

Lodes in the Marshall district contain gold and lead, molybdenum, copper, and tungsten minerals, but none have been productive. The most thoroughly explored deposit, about 7 miles east of Marshall, is in altered volcanic rock and consists of mineralized quartz-calcite veins as much as a foot thick.

Since 1914, placer mining on creeks east of Marshall has resulted in the recovery of possibly as much as 95,000 ounces of gold and a little platinum. The source of most of the heavy minerals probably was nearby narrow mineralized quartz-calcite veins in altered volcanic rock.

No nonmetallic or minable mineral-fuel resources have been discovered, although there are thin coal beds in some of the Cretaceous nonmarine rocks near the Yukon River.

\section{MELOZITNA DISTRICT}

The Melozitna district is the area drained by northern tributaries of the Yukon River between and including the Melozitna and Ray Rivers.

The district is almost entirely within the Kokrine-Hodzana Highlands, a westward extension of the Yukon-Tanana Upland from which it is separated by a narrow trough that is followed for most of its length by the Yukon River. The highlands consist of rolling ridges generally 2,500-4,000 feet in altitude above which a few isolated groups of mountains rise as much as 1,500 feet. The upper parts of some of the major rivers flow in wide swampy valleys choked with alluvium and commonly less than 1,000 feet in elevation.

Bedrock in most of the district is metamorphosed sedimentary and volcanic rocks, mainly of probable Paleozoic age, similar to those that underlie most of the Yukon-Tanana Upland. In the eastern part of the district, a large area northwest of the Yukon River is underlain by the principally volcanic Rampart Group of probable Permian age. Much of the valley of the Melozitna River is in the Cretaceous marine and nonmarine clastic rocks of the southeastern margin of the Koyukuk basin. Granitic plutons of Mesozoic age intruded and further metamorphosed the older rocks in many parts of the district. Pleistocene cirque glaciers developed in the higher parts of the Kokrines Hills and Ray Mountains but have now disappeared. The district is in zones of moderately thick to thin permafrost.

Lode deposits have been found at only three places in the Melozitna 
district. At Gold Hill a gold-quartz vein, discovered in 1890, was the site of the first attempt at lode mining in interior Alaska. The amount of gold recovered, however, was not significant. The other lodes are galena veins about 25 miles up the Yukon River from Tanana and on Tozimoran Creek.

Only a few thousand ounces of gold have been mined from placers in the district. Cassiterite is a common constituent of many of the deposits, and tin concentrates were saved from time to time but may not have been marketed. Although all the placers are within a few miles of known or postulated granitic intrusive bodies, no lode sources of the gold or cassiterite have been found.

Coal-bearing rocks of Tertiary age are exposed on the west bank of the Yukon River opposite the mouth of Hess Creek. At least 1,000 tons of bituminous coal was mined for use on river steamers before 1902 . The economic potential is small, as the coal-bearing rocks are exposed only in a 4-square-mile area in a bend in the river. No deposits of nonmetallic mineral commodities other than material suitable for local use as road metal have been found in the district.

\section{RAMPART DISTRICT}

The Rampart district is the area drained by southern tributaries of the Yukon River between and including Fish and Hamlin Creeks.

The district, entirely within the Yukon-Tanana Upland, is marked by broad ridges $1,500-3,000$ feet in elevation separated by wide valleys. The western part of the area is more rugged than the eastern, with deeper, narrower valleys and several isolated peaks with altitudes greater than 3,500 feet.

Most of the geologic units in the Rampart district trend northeastward and consist of mainly noncalcareous clastic units and chert of Paleozoic age. In the western part of the district and near Livengood, limestone is interbedded with some of the other rocks. A mass of Devonian limestone is in the extreme eastern corner of the district. The probably Permian Rampart Group, which is mainly volcanic but includes some interbedded limestone, chert, and clastic rocks, is exposed along the Yukon River and underlies about half of the district. Cretaceous clastic rocks extend from the adjoining Hot Springs district into the southwestern part of the Rampart district. Tertiary terrestrial conglomerate, sandstone, and shale with a few coal beds were deposited in a local basin near the Yukon River north and west of Rampart. Unconsolidated auriferous terrace gravels east of Minook Creek are of Pliocene age(?). Tertiary granitic plutons were emplaced along the southern boundary of the district. Felsic dikes, probably associated with the plutons, and small mafic dikes, some possibly associated with the volcanic rocks of the Rampart Group, are fairly common in the 
Minook Creek area. From east to west the Paleozoic rocks of the district are progressively more metamorphosed; some are now garnet schists.

Much of the district is mantled by Quaternary residual deposits, alluvium, and loess and, particularly in the Minook Creek area, extensive stream terraces are covered with gravel and finer alluvial material. This part of the Yukon-Tanana Upland was not glaciated. It is in a zone of discontinuous permafrost.

No lode mines have been developed in the Rampart district, though antimony and manganese minerals have been found in bedrock and in float that must be close to its source.

Placer gold was found in 1882 in a northern tributary of the Yukon River and in Minook Creek the next year. Total placer-gold production from the district was about 80,000-90,000 ounces, mainly before 1920 . Nearly all the gold came from the basins of Minook and Troublesome Creeks in the southwest corner of the district. Well over half of the gold mined came from the stream gravels of Little Minook Creek, and much of the rest came from high bench deposits along other streams. The heavy minerals probably were derived from fairly abundant quartz veins and mafic rocks now altered to greenstone although some of the richest placers were probably reconcentrated from older gravels.

No nonmetallic mineral resources have been reported from the district. Little if any of the coal in the Tertiary rocks near Rampart was mined.

\section{RUBY DISTRICT}

The Ruby district comprises the Poorman area and the area drained by southern tributaries of the Yukon River from (and including) the Yuko (Yuki) River on the west to Kallands on the east.

The district includes the eastern part of the Kaiyuh Mountains, the northern part of the Kuskokwim Mountains and a low, poorly drained area that connects the Koyukuk Flats and the Tanana-Kuskokwim Lowland. Broad ridge crests in the mountain provinces are generally less than 2,000 feet in elevation except in the southern part of the district where several are more rugged and about 1,000 feet higher. A few isolated summits in the northern part of the area are above 3,000 feet and Von Frank Mountain, on the divide between the Yukon and Kuskokwim drainages, is 4,508 feet in elevation. The lowlands are poorly drained areas of low relief, mainly less than 500 feet above sea level, through which streams meander in wide belts characterized by many oxbow lakes.

The district is mainly underlain by Precambrian(?) and Paleozoic crystalline limestone, schist, and other metamorphic rocks generally similar to those in the Yukon-Tanana Upland and by altered volcanic rocks. In the southern part of the district and near Yuki Mountain, 
early Paleozoic carbonate rocks are exposed. Near Poorman, Cretaceous chert and argillite are interbedded with coarser clastic and volcanic rocks. Cretaceous and probable Tertiary granitic plutons invaded the older rocks in many parts of the district, but only small intrusive bodies have been found in areas with known mineral deposits. The district was not glaciated. Large areas are covered by weathered residual material and unconsolidated alluvium and terrace deposits, most of which are perennially frozen.

A silver-lead deposit in metamorphic rocks about 10 miles south of Ruby is the only described lode in the district. Although an unknown, but certainly small, amount of ore was mined, the venture was abandoned in the 1930's. Other mineralized zones are probably hidden by the thick mantle of residual debris that generally supports a heavy growth of vegetation and effectively hides bedrock even on most ridges. Gold nuggets with intergrown quartz, as well as the mineral suites in some placer concentrates, suggest that the creeks drain mineralized zones around granitic plutons.

Thin beds of subbituminous coal of probable Cretaceous age were found in placer prospect holes near Poorman. At most only a few tons was mined for local use; it was not good blacksmith coal and slacked badly. No nonmetallic mineral resources have been found.

Placer gold was discovered in the district in 1907, but sustained production did not begin until several years later. Most of the mining was on Long Creek and its tributaries about 25 miles south of Ruby and near Poorman in the headwaters of the Innoko River drainage. Total production was 390,000-400,000 ounces of gold (1.9 percent of Alaska's total placer gold output), about 10 tons of byproduct tin concentrate, and a few ounces of platinum separated from the concentrates from one creek. Most of the placer deposits are in buried channels that could be located only by random shaft sinking. Cassiterite is a common constituent of many of the placer deposits, but no bedrock source for it or for the gold has been found.

\section{SHEENJEK DISTRICT}

The Sheenjek district is bounded on the west by the drainage divide east of the East Fork of the Chandalar River, on the north by the crest of the Brooks Range, and on the east by the Alaska-Yukon boundary. Its southern border is an arbitrary line extending eastward from Venetie on the Chandalar River to Graphite Point on the Porcupine River, beyond which it follows the divide between the Porcupine and Black Rivers to the Canadian boundary.

The Sheenjek district is mainly in the Porcupine Plateau and Brooks Range physiographic provinces; the lower parts of the valleys of the Sheenjek and Christian Rivers are in the Yukon Flats province. Peaks 
marking the crest of the Brooks Range are 4,000-7,000 feet in elevation except near the Alaska-Yukon boundary where they are lower and separated by a few passes below 3,000 feet. The Brooks Range merges southward with the rounded ridges of the Porcupine Plateau and the low (less than 1,000 feet), swampy Yukon Flats.

The bedded rocks in the district are mainly Paleozoic and Mesozoic clastic, carbonate, and volcanic rocks. Some of the sedimentary rocks may be as old as Precambrian, and some of the volcanic rocks are as young as Quaternary. Near the boundary between the Yukon Flats and the Brooks Range, many of the rocks have been regionally metamorphosed to schist and phyllite. In the eastern part of the district, two Carboniferous granitic plutons intruded Paleozoic rocks. A large Jurassic mafic igneous complex intruded Paleozoic rocks in the west-central part of the district. The Yukon Flats are composed of Quaternary alluvial fan and related terrace deposits, beneath which aeromagnetic data suggest large areas underlain by mafic rocks.

Only the northern part of the district was glaciated, though glaciofluvial deposits make up much of the Quaternary deposits in the lowlands. Some of the peaks at the head of the Sheenjek River still support small glaciers. Most of the district is in zones of continuous permafrost, though in parts of the northern Yukon Flats perennially frozen ground may be locally absent.

No mineral resources have been exploited in the Sheenjek district. Copper or lead sulfide minerals have been found in two places, and a little placer gold has been reported from the Coleen River drainage basin. Oil shale occurs in the Christian River basin but has not been thoroughly investigated.

\section{TOK DISTRICT}

The Tok district is the area drained by southern tributaries of the Tanana River between (and including) Berry Creek and the Tetlin and Kalutna Rivers. Most of the district is on the northeast flank of the Alaska Range, which slopes from Mount Kimball (10,300 feet) to lowlands along the Tanana River that are about 1,500 feet above sea level. Ice, remnants of Pleistocene glaciers that covered most of the Alaska Range, persists around Mount Kimball and other high mountains and flows several miles down some of the larger valleys. Discontinuous permafrost underlies the district.

Bedrock is mainly Paleozoic and Mesozoic clastic and volcanic rocks, large Mesozoic granitic plutons, and smaller bodies of older more mafic intrusive rocks. The lowlands are mantled by unconsolidated fluvial and glacial deposits largely derived from the Alaska Range. A stibnite prospect in a shear zone in schist on a tributary of the Tok River and an occurrence of several metallic minerals near the highway between 
Gulkana and Tok Junction have not been productive, although the stibnite prospect was fairly extensively explored. Only two occurrences of placer gold have been reported in the district, and neither proved to be of economic interest. A little nephrite jade was found near Mentasta Pass; there has been no production from this prospect.

\section{TOLOVANA DISTRICT}

The Tolovana district is the area drained by southwest-flowing tributaries of the Tanana River from Dugan Creek on the west to the Tolovana River on the east. The drainage basin of the Chatanika River above the mouth of the Tatalina River is not included. The district is bounded on the north by an arbitrary line dividing the lowlands of the Yukon Flats from higher ground drained mainly by upper Beaver Creek.

Most of the district is in the Yukon-Tanana Upland and is characterized by broad even-topped ridges with an average summit elevation of about 2,000 feet above which elongate mountain masses rise $2,000-3,000$ feet. In general the valley floors are wide and occupied by widely meandering streams. The lower part of the Tolovana River valley is a broad, low, lake-dotted, marshy area through which the main stream and the lower parts of its tributaries flow in tortuous channels. This part of the district is in the Tanana-Kuskokwim Lowlands province.

The southern part of the district, geologically an extension of the adjacent Fairbanks and Circle districts, is a metamorphic terrane of schists and related rocks of Precambrian(?) and early Paleozoic age. To the northwest these rocks are succeeded by northeastward-trending belts of slightly metamorphosed Paleozoic clastic, volcanic, and carbonate rocks and chert. Lower Cretaceous clastic rocks underlie an area in the western part of the district. Diorite, quartz monzonite, granodiorite, and granite plutons and dikes, mainly of Mesozoic age, are common in the district. A belt of serpentinite bodies of Devonian(?) age extends northeastward from Livengood for many miles. Evidence of more than one Pleistocene glaciation has been found on the higher peaks, but all are now ice free. The district is mainly within a zone of discontinuous permafrost; many south-facing slopes are not perennially frozen. The flats in the lower valley of the Tolovana River generally are underlain by moderately thick to thin permafrost and numerous isolated masses of frozen ground.

Lodes in the Tolovana district have been found only in the area immediately around Livengood and on Sawtooth Mountain about 30 miles to the west. They contain gold, silver, antimony, mercury, chromium, nickel, and iron. However, only small amounts of antimony ore from Livengood and Sawtooth Mountain and a little mercury from 
Livengood have been recovered from lode sources. One of the serpentinite bodies near the head of the Tolovana River contains abnormally large amounts of nickel and detectable platinum and palladium. Many of the placer cuts near Livengood have uncovered quartz and calcite veins that contain gold and sulfide minerals; similar veins have been found in nearby hills.

At least 380,000 ounces of placer gold (1.9 percent of the total for the State) has been mined from creeks in the area near Livengood and from Nome Creek in the southeast corner of the district. The most productive placers near Livengood are old buried stream channels, one of which was followed for about 4 miles, and stream placers in which gold from old channels was further concentrated. The gold and other heavy minerals, which include stibnite and cinnabar, were probably derived from the mineralized quartz and calcite veins that are common in placer cuts and the nearby hills. The area around Nome Creek is similar to the neighboring part of the Fairbanks district.

Asbestos occurs in veinlets in serpentinite near the head of the Tolovana River. No mineral fuels are known in the district.

\section{YUKON FLATS DISTRICT}

The Yukon Flats district comprises the relatively flat basin of the Yukon River from Circle to the site of Fort Hamlin (a few miles downstream from Stevens Village), the drainage basin of the Porcupine River below Graphite Point, and the entire drainage basins of the Dall, Hodzana, and Hadweenzic Rivers.

Most of the district is in the Yukon Flats physiographic province, a swampy area of low relief generally less than 1,000 feet in elevation. It is a basin filled with late Tertiary and Quaternary unconsolidated continental deposits, including glaciofluvial material from the Brooks Range to the north, stream deposits derived from the upper Yukon basin, and reworked material forming loess blankets and sand dunes. Near the northwest margin of the basin, older rocks similar to those exposed north of the Yukon Flats have been uncovered beneath the unconsolidated sediments in stream cuts. The Hodzana Highland, an extension of the Yukon-Tanana Upland from which it is separated by a narrow trough followed by the Yukon River, makes up the northwestern part of the district. The oldest rocks are schist, quartzite, and crystalline limestone of early Paleozoic or possibly Precambrian age that were cut by granitic plutons. Sedimentary and volcanic and associated mafic intrusive rocks exposed along the Yukon River are probably Permian; some of the intrusive rocks are probably as young as Triassic. Tertiary continental rocks, including beds of subbituminous coal, were deposited in local basins near the Dall and Hodzana Rivers. 
The only lode reported is on Trout Creek in the northwest margin of the district. Specimens from there contain sphalerite and molybdenite. An unknown, but certainly small, amount of placer gold has been mined from Slate Creek and a tributary, Trout Creek. There has been no other mining in the district.

Some interest has been expressed in the petroleum possibilities of the Yukon Flats basin, but aeromagnetic investigations suggest that much of the area beneath the surficial deposits is underlain by mafic igneous rocks, making the basin a less attractive exploration target than had been anticipated. The coal deposits have not been studied in any detail, and none have been mined.

\section{REFERENCES CITED}

Barnes, F. F., 1967, Coal resources of Alaska: U.S. Geol. Survey Bull. 1242-B, p. B1-B36.

Berg, H. C., and Cobb, E. H., 1967, Metalliferous lode deposits of Alaska: U.S. Geol. Survey Bull. 1246, $254 \mathrm{p}$.

Cobb, E. H., 1972, Placer deposits of Alaska: U.S. Geol. Survey open-file report, 132 p.

Gryc, George, 1971, Summary of potential petroleum resources of Region 1 (Alaska and Hawaii) - Alaska, in Future petroleum provinces of the United States- their geology and potential: Am. Assoc. Petroleum Geologists Mem. 15, p. 55-67.

- Ransome, A. L., and Kerns, W. H., 1954, Names and definitions of regions, districts, and subdistricts in Alaska: U.S. Bur. Mines Inf. Circ. IC-7679, 91 p.

U.S. Geological Survey (prepared in cooperation with State of Alaska), 1964, Mineral and water resources of Alaska: U.S. 88th Cong., 2d Sess., Senate Comm. Interior and Insular Affairs, Comm. Print, $179 \mathrm{p}$.

Wahrhaftig, Clyde, 1965, The physiographic divisions of Alaska: U.S. Geol. Survey Prof. Paper 482, $52 \mathrm{p}$. 